\title{
Gender and Local Floodplain Management Institutions--A Case Study from Bangladesh
}

\author{
Parvin Sultana, Flood Hazard Research Centre, \\ Middlesex University and \\ Paul Thompson, Flood Hazard Research Centre, Middlesex \\ University
}

International Research Workshop on 'Gender and Collective Action' October 17-21, $2005 \cdot$ Chiang Mai, Thailand

The CGIAR Systemwide Program on Collective Action and Property Rights (CAPRi) is an initiative of the 15 centers that belong to the Consultative Group on International Agricultural Research. The initiative promotes comparative research on the role played by property rights and collective action institutions in shaping the efficiency, sustainability, and equity of natural resource systems. CAPRi's Secretariat is hosted by the International Food Policy Research Institute's (IFPRI) Environment and Production Technology Division (www.ifpri.org).

CAPRi Working Papers contain preliminary material and research results and are circulated prior to a full peer review in order to stimulate discussion and critical comment. It is expected that most Working Papers will eventually be published in some other form, and that their content may also be revised.

Copyright (C) October 16, 2006 International Food Policy Research Institute. All rights reserved. Sections of this material may be reproduced for personal and not-for-profit use without the express written permission of but with acknowledgment to IFPRI. To reproduce the material contained herein for profit or commercial use requires express written permission. To obtain permission to reprint, contact the IFPRI Communications Division at ifpri-copyright@cgiar.org.

CGIAR Systemwide Program on Collective Action and Property Rights (CAPRi) c/o INTERNATIONAL FOOD POLICY RESEARCH INSTITUTE 


\section{ACKNOWLEDGMENTS}

This paper is based largely on research undertaken through the Natural Resources Systems Programme (NRSP) of the United Kingdom Department for International Development (DFID). Specifically it includes findings and reports research activities undertaken between 2000 and 2005 as part of: R8306 Better Options for Integrated Floodplains Management- Uptake Promotion, P131 The effectiveness of the PAPD method: a comparison of community organisation experience in the CBFM-2 project, R8118 Understanding livelihoods dependent on inland fisheries in Bangladesh and SE Asia, R8195 IFM institutional environment and participatory methods, and R7562 Methods for consensus building for management of common property resources. In addition evidence from surveys undertaken as part of the Community Based Fisheries Management project supported by the Ford Foundation, and the Community Based Management phase 2 project supported by DFID is used where appropriate. This publication is an output from research projects funded by DFID for the benefit of developing countries. The views expressed are not necessarily those of DFID.

We would like to thank for their advice and suggestions at different times: Christopher Floyd (NRSP), Savitri Abeyasekera (Reading University), Julian Barr (ITAD), Mokhlesur Rahman and Anisul Islam (Centre for Natural Resource Studies). We thank Banchte Shekha for its assistance in the field, and thank Akram Hossain, Habib Ahmed, and Hasib Mahbub (WorldFish Center) for their contributions to the field surveys and data management. Special thanks go to the communities of the study areas in Narail and in particular the members of the community based organizations we have worked with there over the years since 1997. 


\begin{abstract}
Floodplain wetlands are the major common pool natural resource in Bangladesh. Mostly men fish, and both men and women collect aquatic plants and snails. Case studies contrast a women-only, men-only, and mixed community based organization (CBO), each of which manages a seasonal floodplain wetland. The two CBOs in which women hold key positions are in Hindu communities where more women use aquatic resources, work for an income, and belong to other local institutions. In the oldest of these CBOs, more women have gradually become office bearers as their recognition in the community has grown. In the Muslim community, only a few women collect aquatic resources and in this community most women do not perceive floodplain natural resource constraints to be very important to them. These women have no role in the $\mathrm{CBO}$ and feel that they have no say in decisions about the fishery, unlike many women in the other two sites. The fishery management activities in all three sites are similar and catches and biodiversity appear to have improved, demonstrating that women can play an effective role in community organizations for fishery management. Those who are represented in the CBOs reported significant increases in their participation and influence. Men and women in all three sites recognized that decisionmaking and management of their fisheries had improved, but community support and compliance were higher where both men and women had an active role in this process. Women had a more diverse set of criteria for effective CBOs than men. The men-only CBO saw itself as more of a membership based organization than as representing all of the community.
\end{abstract}

Keywords: floodplains, fisheries, Community, Bangladesh 


\section{TABLE OF CONTENTS}

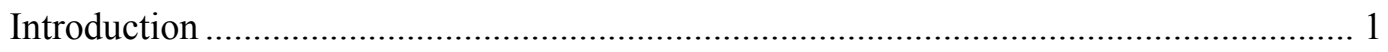

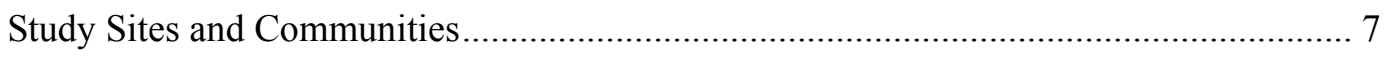

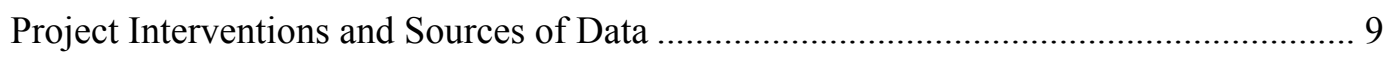

Women's Roles in Aquatic Resource Use in Study Sites ............................................. 13

Floodplain Management Institutions and Role of Women and Men ................................ 15

Impact of Fisheries Institutions in Case Study Locations ............................................ 26

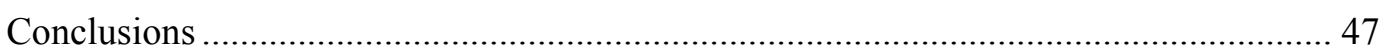

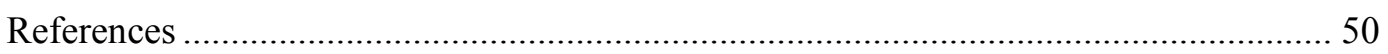

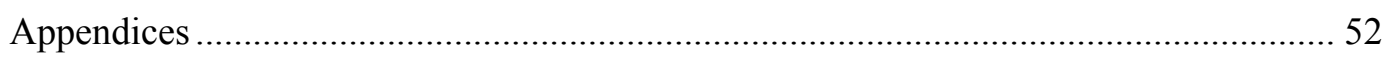




\title{
Gender and Local Floodplain Management institutions--A case study from Bangladesh
}

\author{
Parvin Sultana ${ }^{1}$ and Paul Thompson ${ }^{2}$
}

\section{INTRODUCTION}

\section{Background}

Bangladesh is traversed by numerous rivers and creeks as it is the delta of the GangesBrahmaputra-Meghna rivers. Only 7.5 percent of the 1.5 million $\mathrm{km}^{2}$ catchment area of these rivers lies in Bangladesh (Huda 1989), and the water draining from China, Nepal and India produces a combined peak flow in Bangladesh of about 100,000 cumecs, five times the peak flow of the Mississippi (Coleman 1968), and it may exceed 160,000 cumecs in a 1-in-100 year flood (FAP 4 1993). More than two-thirds of Bangladesh is floodplains and may be classified as wetlands according to the Ramsar Convention's definition ${ }^{3}$. About six to seven percent of Bangladesh is always under water, seasonally 21 percent is deeply $(>90 \mathrm{~cm})$ flooded and around 35 percent experiences shallow inundation (FAO 1988). The wetlands of Bangladesh include mangrove forests, natural lakes, freshwater marshes, baors (oxbow lakes),

\footnotetext{
${ }^{1}$ Parvin Sultana, Flood Hazard Research Centre, Middlesex University, Queensway, Enfield, EN3 4SA, UK (parvin@agni.com)

${ }^{2}$ Paul Thompson, Flood Hazard Research Centre, Middlesex University, Queensway, Enfield, EN3 4SA, UK (paul@agni.com)

3 "Areas of marsh, fen, peatland or water, whether natural or artificial, permanent or temporary, with water that is static, flowing, fresh, brackish or salt, including areas of marine water, the depth of which at low tide does not exceed six meters"
} 
beels (floodplain depressions), fish ponds and tanks, one large reservoir, estuarine areas and extensive seasonally inundated floodplains.

Fishing is traditionally and culturally the preserve of men; fishing by women is limited to their own household ponds or floodwaters near the homestead in the monsoon season. In the past, fish caught by women were seldom sold and any fishing they did was only for family consumption. Access to and control over natural resources by women was virtually unknown. Men believe that fishing is a male activity and women have no role in catching fish.

Therefore, for building fishery management institutions men prefer that only men be included in decisionmaking.

This paper investigates the development of institutions for community management of floodplain and fishery resources vis-à-vis the different roles of women and men in these community-based organizations (CBOs), and the outcomes of the organizations in terms of resource management actions, changes in livelihoods, and changes in assets. The paper focuses on three community-based organizations established mainly for management of capture fisheries; in addition in all three sites smaller groups of poor women were formed for micro-credit, but these were only represented in two of the community-based organizations. Despite similar facilitation from a local NGO (Banchte Shekha) which normally only works with poor women, the three case study sites differ greatly in the extent to which women are involved in resource management decisions and activities.

\section{Floodplain resources}

The four million hectares of inland water bodies and floodplains in Bangladesh are among the word's richest and most complex fisheries. These rivers, beels (lakes), baors 
(oxbow lakes), haors (large deeply flooded depressions), and floodplains support some 260 fish species (Rahman 1989). About 80 percent of rural households catch fish for food or to sell (FAP 16 1995), and about 60 percent of animal protein consumption comes from fish, and of this 80 percent is from freshwater fish (BBS 1997). However, fish consumption has declined between 1995-96 and 2000 by 14 percent to $11.1 \mathrm{~kg} /$ person/year (Bangladesh Bureau of Statistics household expenditure survey data quoted in Muir 2003).

Since the advent of the green revolution, Bangladesh has made tremendous strides in increasing rice production. This success has occurred through many changes in the management of land and water. More areas have been brought under rice production, irrigation has expanded greatly, and areas have been drained and protected by flood control embankments. However, these changes have been at the expense of fish; the area of inland water bodies and the duration of inundation in some areas have fallen, and thereby there has been a reduction in the habitat for fish.

In addition to embankments, drainage and flood control; natural siltation along with over fishing are commonly cited as causes of the deterioration of the country's fishery resources (Hughes et al. 1994; Ali 1997). Yet fisheries remain key floodplain resources, and the restoration of floodplain fisheries through community-based management has the potential to be a major strategy to improve and make more sustainable the livelihoods and quality of food consumed by poor people. The National Water Policy has recently emphasized reserving wetlands for fish in a reversal of past trends (MWR 1999). Previous fisheries policies have discouraged development of local institutions for fisheries protection and management, but this may now be reversed. 
In addition to fisheries, Bangladesh wetlands support a wide diversity of both cultivated and wild food plants. For example 2,929 local varieties of rice have been reportedly used in different regions of the country (NCS 1991). About 13 species of wild wetland plants are eaten (Karim 1993); the grains are used as a substitute for rice, fruits and root stocks; the seeds are eaten raw, roasted or as puffed grain and are also used to make flour; and the stems and leaves are used as vegetables. In addition to almost all species of fish, shrimp and crabs are used as human food, and mollusks are used both as feed for domestic ducks and in freshwater prawn culture. Wetland plants are also used as fodder and medicine, for mat making and fuelwood, and to protect homesteads against wave erosion.

\section{Status of Women in Bangladesh}

The majority of rural women in Bangladesh are not only poor but are also caught between two very different domains: one determined by culture and tradition that confines their activities inside homesteads and the other shaped by increasing landlessness and poverty that forces them outside into wage employment. Women from poor and female-headed households by necessity take culturally unaccepted work as laborers in garment industries in the urban areas, fish processing, brick breaking, earthwork for road construction and road maintenance.

The role of women in society is seen as subsidiary to that of men and as having its principal concern with the household, reproduction, childcare and family management. The distortions show particularly in:

- $\quad$ average literacy - 38 percent for women, 52 percent for men (BBS 1998);

- $\quad$ age at first marriage - 20 for women and 28 for men (World Bank 1998); 
- education enrollment rates - women compose only about 30 percent of the secondary and higher roll (BBS 1998) and;

- labor force- only 18 percent of women participate in the labor force compared with 43 percent of men (United Nations 2000), and have significantly lower wages when they do, but contribute 80 percent of the unpaid family work.

Since the 1980s, the status of women and the amelioration of their disadvantaged position in Bangladesh has been a major concern of the NGO movement. Whatever the limitations, there have been impressive strides in the empowerment and economic emancipation of women under the programs of the major national NGOs, which have raised the economic role and voice of women in rural society. Only over the last two decades have policy-makers, planners, researchers and society in general begun to consider and value women's economic contribution to food production and income generation.

\section{Gender roles in fisheries and other aquatic resources management}

In Bangladesh, fishing is the second most important occupation in the non-farm sector. Traditionally, only men in the fishing communities were engaged in catching fish, although some old and widowed Hindu women did catch fish for their household consumption as well as for sale in the southern part of the country. Now not only do old and widowed women fish, but all poor women irrespective of religion, age and marital status are found to catch shrimp fry in the coastal areas of Bangladesh. About 80 percent of the work force in shrimp fry collection is women and children. This change has happened due to extreme poverty and the growth of shrimp farming which has created a low cost way of earning money. In 2000, the 
price of each shrimp fry was around Tk. 1-2 and on average each woman could earn about Tk. 5,000 (approximately US\$ 95) in a fry catching season (January to March).

Although fry catching by women is quite accepted in the coastal areas, fishing by women in inland water is not yet a common site. Some Hindu women catch fish in the canals and water bodies near their houses with rods and hooks, rarely with cast nets. Women also catch fish by hand in shallow water and paddy fields, particularly in the coastal areas.

In shrimp processing plants, 80 percent of the work (such as deheading, sorting, peeling of small shrimps, and packing) is done by women while men break ice slabs for preservation. More generally in inland fisheries most of the post-harvest work such as drying fish is done by the women. Women also are responsible for storing processed fish. Gears such as nets and traps are made mostly by women and other family members. When the men sit idle or do not go out fishing they help in net making. Mending and cleaning nets are mostly done by men, but tanning is solely done by the women.

Women also collect snails and aquatic plants. They sell snails to the duck and prawn farmers. Sometimes traders buy snails and they engage women as paid laborers to break the snails. This snail trade has become a very popular business in the southwest of Bangladesh where there has been a rapid expansion of shrimp and prawn farming. While this provides an additional income source for women who are able to access snails freely, it is increasingly thought by local people (men and women) that there is now an overexploitation of snails.

In most of Bangladesh, men make fishing related decisions, such as when to fish for income and food, whether to preserve any fish, what to purchase with the money earned, and even what to purchase from women's income, as they are mostly fishing and earning from it. 


\section{Study Sites and Communities}

Beels are natural depressions where water stands during the monsoon, and in the monsoon there is open access for fishing for members of the surrounding communities. Rain water and daily tidal influences are the main sources of seasonal flooding. All three of the sites covered by this study are protected by flood control embankments constructed along the rivers by the Bangladesh Water Development Board (BWDB).

\section{Goakhola-Hatiara Beel}

Goakhola-Hatiara Beel is a seasonal floodplain beel covering at its maximum extent around 250 ha. The beel is connected by Goakhola Khal (a natural canal) via a sluice gate to Afra Khal (a secondary river), which connects to Bhairab river some $3 \mathrm{~km}$ downstream of the beel, but local rainfall is the main source of water in the beel. All of the lands within the beel are privately owned and are cultivated mainly with paddy in the dry season. The area is under approximately $1.2-1.8 \mathrm{~m}$ of water for five to six months of the monsoon each year. During the monsoon, paddy is also grown on much of the area (and very recently has changed from traditional mixed aus and aman paddy to early monsoon (aus) paddy). Land owners have shallow ditches (locally called kua) in their land where no crop is grown but where they trap water and fish at the end of the monsoon and by the end of the dry season they drain out all the water and catch the fish. The five villages around the beel (Hatiara, Goakhola, Bakri, Mandiarchor and Debbhog) are entirely Hindu communities. In December 1996 there were 355 households living around the beel, of which 89 were already NGO (Banchte Sekha) group members. 
As all the land is private, farmers dominate in the area and as this is a floodplain and the community is a Hindu farming community, the number of professional fishers is very negligible. Access to aquatic resources during the monsoon is free for all from the surrounding villages owning land in the beel. Anyone can fish anywhere in the monsoon, but in the post monsoon period nobody is allowed to fish near the private kuas. In the nearby Bhairab river, high competition for fishing exists and the Hindu community does not feel comfortable fishing there throughout the year. Thus, the poor, including the landless poor, do not depend always on fishing. Most of the households catch fish at some point in the year, over a third sell fish, and the remainder fish only for their own consumption.

\section{Maliate Beel}

Maliate Beel covers 100 ha of private land just east of Goakhola-Hatiara Beel, and the two beels are interconnected with another three seasonal beels in the monsoon. Water stays permanently in only 3 percent of the area. One channel from the beel area is connected to the

river. During the dry season 70 percent of the low-lying land is cultivated with irrigated high yielding varieties of paddy, while the rest of the land is cultivated with other winter (rabi) crops. The few high lands are occupied by homesteads. The four villages around the beel are inhabited by 591 households. They are all lower caste Hindus.

\section{Shuluar Beel}

Shuluar Beel is a seasonal beel (flooded in the monsoon season), and is larger than the other two beels, covering at its maximum extent around 1,000 ha. It is located in Narail district in southwest Bangladesh. The beel is connected by a canal to the rivers Chitra and 
Nabaganga (secondary rivers), but rainfall is the main source of water in the beel. All of the land in the beel is private and is cultivated mainly with paddy. There are around 967 households living in five villages around the beel. Approximately 90 percent of households are Muslim. The beel is seasonal and in the monsoon there is open access for fishing for members of the surrounding communities. Almost all of the households catch fish at some point in the year. Half of the households that depend on fishing and other aquatic flora and fauna for income are very poor; the other half of the households just fish for their own consumption.

\section{Project Interventions and Sources of Data}

\section{Project approaches}

The community of Goakhola-Hatiara Beel has since November 1996 been supported by projects to establish community based management of the fishery. An NGO, Banchte Shekha, from the region that only works with poor women has facilitated this with support from the government and WorldFish Center, and the focus has been on conserving fish in the dry season (Thompson et al. 2003). In late 2001, Maliate and Shuluar Beels were added to the same program in a second phase of the Community Based Fisheries Management (CBFM) Project (WorldFish Center 2003). The general CBFM model adopted in the three sites is to include representatives from all types of stakeholders in the Beel Management Committees (BMC). The institutions themselves were formed through selection by the community members, NGO staff and the local fishery department. 
The approach in two beels - Goakhola and Shuluar - included: stakeholder analysis; informal grouping according to livelihood characteristics; developing consensus on the livelihood categories and among all stakeholders on problems, constraints and possible solutions; and analysis of social, economic and environmental impacts of the solutions. In both cases the local community formed a BMC with all types of stakeholders in the floodplain, but gave priority to the fishers, although the number of full time fishers in these beels is very few.

The approach adopted in Maliate Beel involved all stakeholders but identified women as the main stakeholders interested in taking action based on past experience in Goakhola (Figure 1). 


\section{Figure 1--CBFM approach adopted in Maliate Beel}

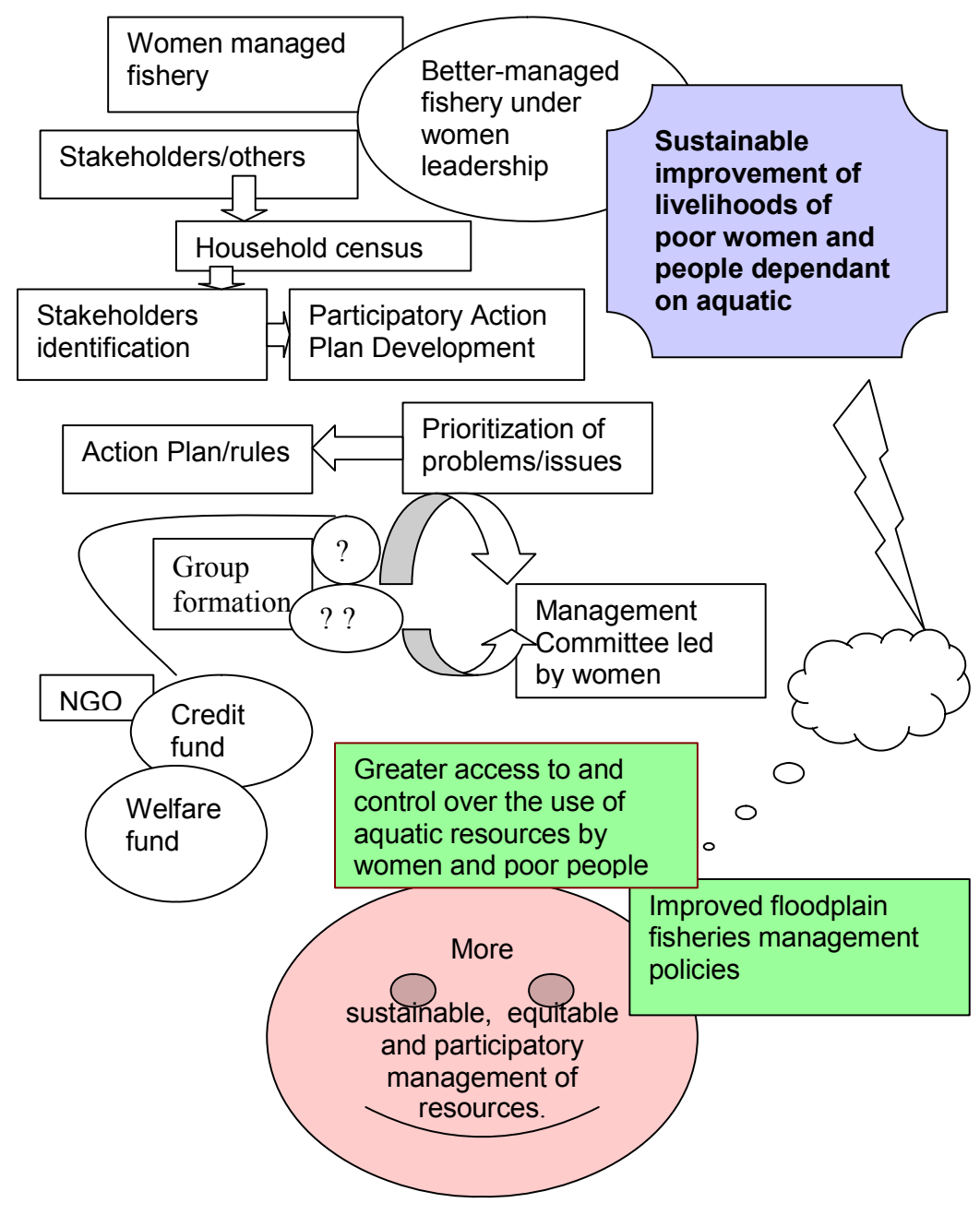

The NGO formed groups with the women for income generating activities. There, other stakeholders in the community participate as members of the advisory committee.

In addition, from mid-2003 Integrated Floodplain Management (IFM) has been promoted in Goakhola-Hatiara Beel through a research project involving the same agencies (Sultana et al. 2005), with implications for the local institutions. The focus of the IFM approach has been to improve overall floodplain productivity by better understanding the links between private and common pool resources and decisions of individual farmers and 
collective action. For example, it has facilitated farmers (who also catch fish for food) in testing and then adopting alternative dry season crops that do not require irrigation and thereby reduce abstraction of surface water for irrigation, resulting in more water in the dry season which is a critical habitat for fish that is now protected by the community.

\section{Data sources}

Studies undertaken by the CBFM-1 and 2 projects since 1996 to understand the fishery and impacts of management changes in Goakhola-Hatiara have included: baseline household surveys of 60 participant households of the groups organized by the NGO Banchte Shekha and of 60 non-participant households in 1996; regular monitoring by local women of fishing and fish consumption for 30 participant and 30 non-participant households for a week each month since 1997; monitoring of fish catches and effort in the beel twice a month by a research assistant since 1997; and impact surveys in 2001. In all three beels, baseline household surveys stratified by poverty level and fishing involvement were conducted in 2002, and fish catches have been monitored. In addition for 40 households in each of Goakhola and Maliate Beels and 50 households in Shuluar Beel the number of days that men and women were involved in aquatic resource related activities and in other occupations was monitored for each month in 2003 and 2004.

As part of a study of institutional issues for integrated floodplain management, focus groups were held with all of the BMCs in 2003. As part of the project to promote uptake of IFM approaches, participatory planning was undertaken in Goakhola-Hatiara and Maliate Beels, and data were collected on agricultural changes, water levels and fish catches. In addition, as part of that study household impact surveys were undertaken for all three sites in 
August 2005. Moreover at different times, participatory assessments and learning sessions with focus groups comprising representatives of each stakeholder group were held.

\section{WOMEN'S ROLES IN AQUATIC RESOURCE USE IN STUDY SITES}

In general, women of ethnic and other minority groups are more liberated and more outspoken than the rural Muslim women in Bangladesh. Two of the case study sites Goakhala-Hatiara and Maliate Beels - are Hindu communities, where about 90 percent of women fish seasonally for food and income. About 60 percent of women and children catch snails for household use or for income, and about 10 percent of women are employed as snail breakers. However, the scenario is different in Shuluar Beel, where the majority of the people in the community are Muslim and conservative. Men take all the decisions and women remain within the house. Men do not want their women to join in any group or organization.

The data from monitoring household activities in 2003 and 2004 has been summarized for the main natural resources (Figures 2a-2e). Fishing was a major activity for men averaging about 80 days a year in all three beels (slightly less in Shuluar). On average at least one woman (including girls) from a household spent about 40 days a year fishing in both Goakhola and Maliate (Hindu communities), but no women were involved in fishing in Shuluar (Figure 2a). 

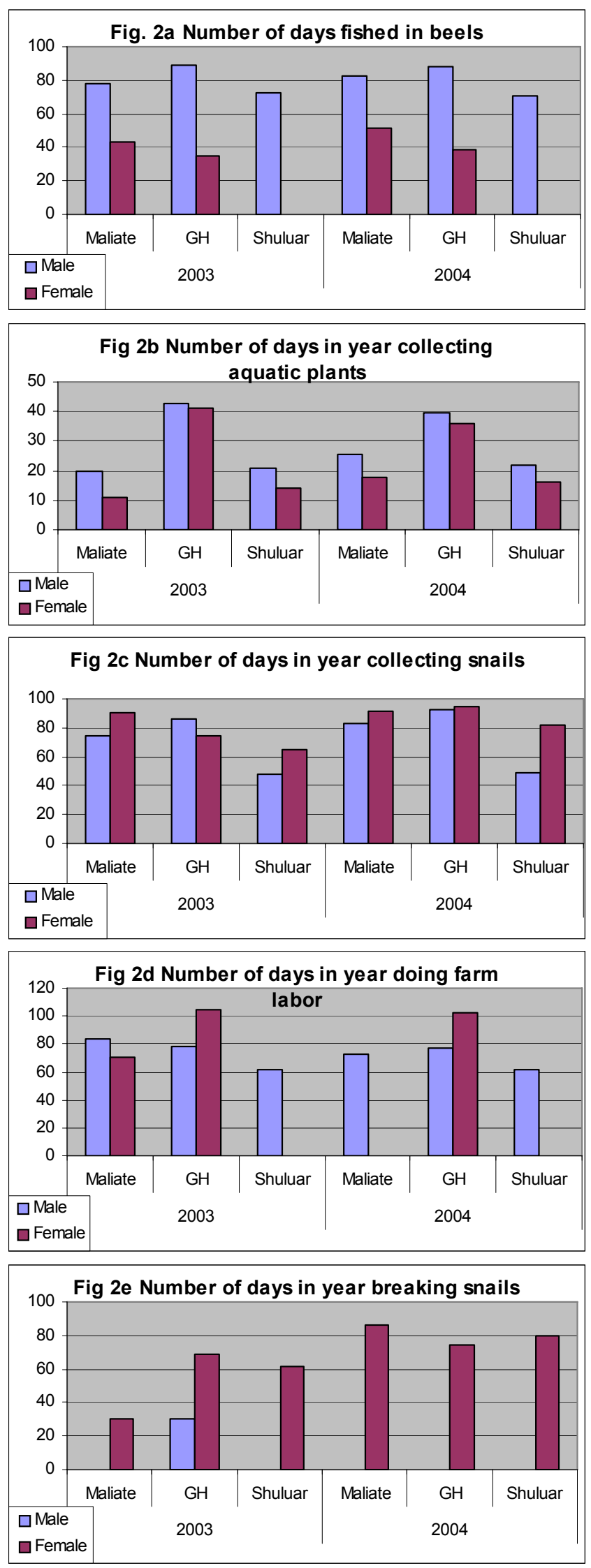
The patterns were similar to this for day laboring - no women did this work in Shuluar, but in the other two beels women were just as likely as men to do daily laboring work in both 2003 and in 2004 (Figure 2d).

Although in Shuluar Beel women are not involved in fishing or day laboring, they collect aquatic plants and snails and break snails for selling or work as snail breakers for traders. These women are from very poor families who have no men in the family to provide an income. Snail collection only happens in the early morning and when snails can easily be caught as they float on the water surface; this is also when fewer men are around. Women break snails at home and sell to traders who come to their homes. In contrast, in the other two beels women from all categories of households catch snails whenever they have time, including when they are fishing (but they are also busy in their farm or working on others' farms and they do post harvesting work too).

\section{FLOODPLAIN MANAGEMENT INSTITUTIONS AND ROLE OF WOMEN AND MEN}

\section{Goakhola-Hatiara Beel}

The Beel Management Committees involved in CBFM activities start with the representatives from NGO (Banchte Shekha) primary groups. Each primary group has 10-15 members, all female. The female group members save regularly and have their own income generating activities (IGAs) and all the members are not necessarily involved in fishery activities. The BMC is a selected body comprised of group representatives, representatives of 
other stakeholder categories and local leaders whom the community and NGO select to be in the committee. BMC members meet every month but if there is an emergency they meet any time. They receive training on leadership development, waterbody management, fisheries management and accounting. All the members are literate and they have some technical knowledge. Women members also receive training on different IGAs and most of them are running individual enterprises.

As the NGO has no male groups, there is no direct way of supporting households dependent on men who fish for an income to divert from fishing during the closed season (fish breeding season when fishing is prohibited by the committee in order to conserve fish). But credit is disbursed through the female groups to women from those poor fisher households.

The Beel Management Committee (BMC) was formed in 1997 with representatives from a mixture of professions in the community. Most of them are farmers and fishing is their seasonal activity. The committee has always contained several women, all of whom are members and representatives of the groups formed by Banchte Shekha. Table 1 shows how the committee has evolved since 1999. Representatives of two villages, Goakhola and Hatiara, dominate in the committee. 
Table1--History and composition of Goakhola-Hatiara Beel Management Committee

\begin{tabular}{|c|c|c|c|c|c|c|}
\hline \multirow[t]{2}{*}{ Year } & \multicolumn{2}{|c|}{ General Body } & \multicolumn{2}{|l|}{ Office bearers } & \multirow{2}{*}{$\begin{array}{l}\text { Executive } \\
\text { Committee }\end{array}$} & \multirow{2}{*}{$\begin{array}{l}\text { Advisory } \\
\text { committee }\end{array}$} \\
\hline & Male & Female & Male & Female & & \\
\hline 1999 & 19 & 8 & $\begin{array}{l}\text { President, Vice } \\
\text { President, General } \\
\text { Secretary, Cashier }\end{array}$ & Only members & None & None \\
\hline 2000 & 19 & 8 & $\begin{array}{l}\text { President, Vice } \\
\text { president, General } \\
\text { Secretary }\end{array}$ & $\begin{array}{l}\text { Asst Secretary, } \\
\text { Cashier }\end{array}$ & None & 5 men \\
\hline 2001 & 19 & 8 & $\begin{array}{l}\text { President, Vice } \\
\text { president, General } \\
\text { Secretary }\end{array}$ & $\begin{array}{l}\text { Ast. Secretary, } \\
\text { Cashier }\end{array}$ & None & 5 men \\
\hline 2002 & 22 & 9 & $\begin{array}{l}\text { President, Vice } \\
\text { president, General } \\
\text { Secretary }\end{array}$ & $\begin{array}{l}\text { Cashier, } \\
\text { Communication } \\
\text { secretary }\end{array}$ & None & 5 men \\
\hline 2003 & 13 & 14 & $\begin{array}{l}\text { President, Vice } \\
\text { president, General } \\
\text { Secretary }\end{array}$ & $\begin{array}{l}\text { Cashier, } \\
\text { Communication } \\
\text { secretary }\end{array}$ & None & 6 men \\
\hline 2004 & 16 & 11 & $\begin{array}{l}\text { President, Vice } \\
\text { president, General } \\
\text { Secretary, } \\
\text { Assistant } \\
\text { Secretary, }\end{array}$ & $\begin{array}{l}\text { Cashier, } \\
\text { Communication } \\
\text { secretary, } \\
\text { Organizing } \\
\text { secretary, Women- } \\
\text { issue secretary }\end{array}$ & $\begin{array}{l}8 \text { men, } \\
9 \text { women }\end{array}$ & None \\
\hline
\end{tabular}

The main activity of the BMC has been to take up fish conservation measures and it tried unsuccessfully to extend to water control The BMC is also responsible for coordination with other stakeholder groups as well as different organizations. It takes decisions through participatory discussion with the primary groups. The women members of Banchte Sekha guard kuas which they have protected as dry season fish sanctuaries in the day time while men in the $\mathrm{BMC}$ and husbands of the women guard at night. The BMC members, aided by public announcements, inform the general community not to poach in these kuas. 
To coordinate between villages, there was a male advisory committee composed of elderly people and local elites until 2003 . The advisory committee was responsible for providing necessary support to the BMC and to liaise with the local government for back-up support.

The BMC has succeeded in implementing the local rules that it sets through guarding by women and men and the support of men and women including local leaders, and claims that only 10 percent of the community breaks the rules. Some people who were fishing illegally during the closed season were subject to punishment of different levels when caught by the BMC members. The BMC has a bank account jointly operated with the NGO staff member supporting their activities. Each member makes contributions to the fund. The CBFM project provided some revolving fund and grants, and the entire fund was deposited in the account. Moreover, the BMC successfully appealed to the Union Parishad (local council) chairman and got the lease to the khal (canal) without any fees imposed for making it into a fish sanctuary. The BMC has a small community center located next to the beel. The land was donated by one of the BMC members, and the structure was built through a CBFM-2 grant. For proper identity and formal recognition, the BMC should be registered with the government; however this has not been done yet as the Social Welfare Department ended new registrations in 2005.

This arrangement was modified in 2002 when representatives from the BMC, farmers, fishers, farmer field school and sluice gate operators formed an integrated floodplain management committee. This committee is working as an apex body and coordinates the activities of all the local institutions. In this 15 -member committee six women are also included from the BMC and from the farmer field school. 


\section{Maliate Beel}

The institutional arrangement for CBFM in Maliate Beel is similar to that for GoakholaHatiara Beel, with an important difference being that, given the strength of its primary groups in this area, Banchte Shekha helped them to form a BMC that comprises only women from its primary groups. Women here observed that fishery resources are continuously depleted and there was no conservation for the future generation. They first discussed this with the men, but men were not interested in forming any institutions to improve fishery management. However, these women sought the help of respected men from the community as an advisory committee, since they could more easily persuade men to follow the BMC rules in a male dominated society. Thus, women have taken a lead in fishery conservation and management in the beel. Not everyone in the community though has accepted the leadership of women in fishery management. Some men raised questions about the competence of women in future management. A few started to catch fish in order to see how women ensured compliance with the rules the BMC set on fishing. Although women were guarding the sanctuaries during the day time, at night it is not physically safe for women to be in the beel so the women successfully asked their husbands to guard. As shown in Table 2, the women felt the need to involve some men at least in an advisory committee. This advisory committee included locally respected people who have substantial influence on the community. The advisory committee members talked to anyone who broke the rules in order to make them aware about the future impacts of not protecting fish, and subsequently the BMC reported nobody from the community broke the rules. This committee also negotiates with the local government to support water retention and fish sanctuaries, and helps the women of the BMC to make linkages with local experts and officials. 
Table 2--History and composition of Maliate Beel Management Committee

\begin{tabular}{|c|c|c|c|c|c|c|}
\hline \multirow[t]{2}{*}{ Year } & \multicolumn{2}{|c|}{ General Body } & \multirow{2}{*}{ Executive Committee } & \multicolumn{2}{|r|}{ Office bearers } & \multirow{2}{*}{ Advisory committee } \\
\hline & Men & Women & & Men & Women & \\
\hline 2002 & 0 & 24 & none & None & $\begin{array}{l}\text { President, Vice president, General } \\
\text { Secretary Cashier, Communication } \\
\text { secretary, Organizing secretary, } \\
\text { Women-issue secretary }\end{array}$ & 7 male, 1 female \\
\hline 2004 & 0 & 24 & 17 members & None & $\begin{array}{l}\text { President, Vice president, General } \\
\text { Secretary, Cashier, Communication } \\
\text { secretary, Organizing secretary, } \\
\text { Women-issue secretary }\end{array}$ & 5 male \\
\hline
\end{tabular}


Maliate BMC is registered with the social welfare department, giving it a legal identity. They have group savings, a rolling credit fund for income generation activities for women, and a fund for the BMC. The chairperson has been selected to be the vice president of the District Committee Against Women's Repression and also secretary of the beel Cluster Committee that coordinates management of five connected beels including Goakhola and Maliate Beels.

Because it is adjacent to Goakhola-Hatiara Beel and links with it in the monsoon, IFM has effectively been extended from Goakhola to Maliate. The BMC members and farmers have been invited to IFM activities such as field days, participatory assessments and exchange visits. After seeing the IFM committee in Goakhola, the community in Maliate also formed a similar 15 member IFM committee, but most (nine) of its members are women and come from the BMC and most of the men come from its advisory committee.

\section{Shuluar Beel}

Before the CBFM project this beel never had any local institution for resource management or any development work. The community comprises mostly of Muslims and women's voices are not heard. In this area, NGOs were not allowed to work freely with women. Banchte Shekha only works with women and when they started the CBFM-2 project they faced problems for forming women's groups. The men did not allow women to take part in the BMC and no women were included in any committee (Table 3). Even during the Participatory Action Plan Development (PAPD) workshop, women were not allowed to come to the plenary for discussion. After forming the BMC the committee needed funds for establishing sanctuaries, and men wanted credit for alternative occupations during the closed season. Banchte Shekha refused to lend money to the men and they kept motivating BMC members to allow women to be part of 
the fishery development work. After one year, the men allowed women to form a few groups. Women are now receiving credit and the men have become used to it. After several meetings, the BMC felt that women could be a good publicity link as they talk with other women during leisure time or visits to their kin. They decided to add two women to the committee. However, the original BMC was large and members were not attending meetings regularly, so in 2003 they reduced the number in the general body and formed a nine-member executive committee of the active people but did not include any women; and the members of the general body (including the two women there) do not have a role in decisionmaking. There has been no change in the committee membership or numbers since 2003 . The BMC reported that about $20 \%$ of the community still breaks their resource management rules.

Table 3--History and composition of Shuluar Beel Management Committee

\begin{tabular}{|c|c|c|c|c|c|c|}
\hline \multirow[t]{2}{*}{ Year } & \multicolumn{2}{|c|}{ General Body } & \multirow{2}{*}{$\begin{array}{c}\text { Executive } \\
\text { Committe } \\
\mathrm{e}\end{array}$} & \multicolumn{2}{|c|}{ Office bearers } & \multirow{2}{*}{$\begin{array}{l}\text { Advisory } \\
\text { committee }\end{array}$} \\
\hline & Men & Women & & Men & Women & \\
\hline 2002 & 39 & 0 & none & $\begin{array}{l}\text { President, Vice } \\
\text { president, } \\
\text { General } \\
\text { Secretary } \\
\text { Cashier }\end{array}$ & None & None \\
\hline 2003 & 29 & 0 & $\begin{array}{c}9 \\
\text { members }\end{array}$ & $\begin{array}{l}\text { President, Vice } \\
\text { president, } \\
\text { General } \\
\text { Secretary } \\
\text { Cashier }\end{array}$ & None & None \\
\hline
\end{tabular}

No change after 2003, but Banchte Shekha formed women groups 


\section{Comparison of changes in beel management committees}

The roles of women and men in Goakhola-Hatiara Beel have changed over time. This site has the longest history of CBFM and has always had men and women in its CBO. Between 1999 and 2002 about 30 percent of the committee members were women; in 2003, the number increased to 52 percent, but in addition from 1999 to 2002 there was a male advisory committee to help with liaison activities and convincing people to observe the BMC rules. Moreover, in 1999 all four office bearers were men so the level of women's involvement in decisionmaking was limited, but then in 2000-2003 two out of five office bearers were women. In 2004 the advisory committee was dropped, an executive committee was formed with 52 percent of its members being women, and half of the eight office bearers were women. Thus over time women have become accepted by men as playing a more active role in decisionmaking and now they have a roughly equal role to men.

There have been no effective changes in the last three years in the other two sites: Maliate has only women in the committee, but has a male advisory committee which the women wanted as it helps them for linking with local institutions and obtaining help for night time guarding. Shuluar has throughout had all male decisionmaking committees; although in 2003 women's groups were formed for savings and credit they are not represented in decisions on fishery and floodplain resource management.

These differences between sites are also reflected in the establishment of community centers: in both beels where women are involved, it was women office bearers who donated land to build a community center, whereas the men-only $\mathrm{CBO}$ negotiated with a male 
landowner who was not active in the CBO to temporarily make land available, and thus the CBO's tenure is less secure.

5.5 Beel Cluster Committee and Links with Other Institutions

At the field level the fishing community is represented by the Beel Management Committee that is supported by the NGO (Banchte Shekha), with technical advice from the Department of Fisheries (DoF). All partners also receive advice and facilitation from WorldFish Center as needed. Wider linkages for the BMC are made with a network of similar CBOs and local government - the Union Parishad mainly.

Under CBFM-2, the BMCs from the adjacent beels formed a cluster committee (Figure 3) in 2003. The cluster committee is composed of seven members, one from each beel plus a member from DoF. The cluster committee was formed to strengthen all the individual BMCs and to help them develop a unified action plan so that all the water bodies in the same connected cluster benefit from one another's management activities equally. It acts as a local conflict resolution body. This committee also works as a pressure group for any fisheries policy implications. 
Figure 3--Institutional Structure and Linkages for fisheries management in Goakhola Cluster

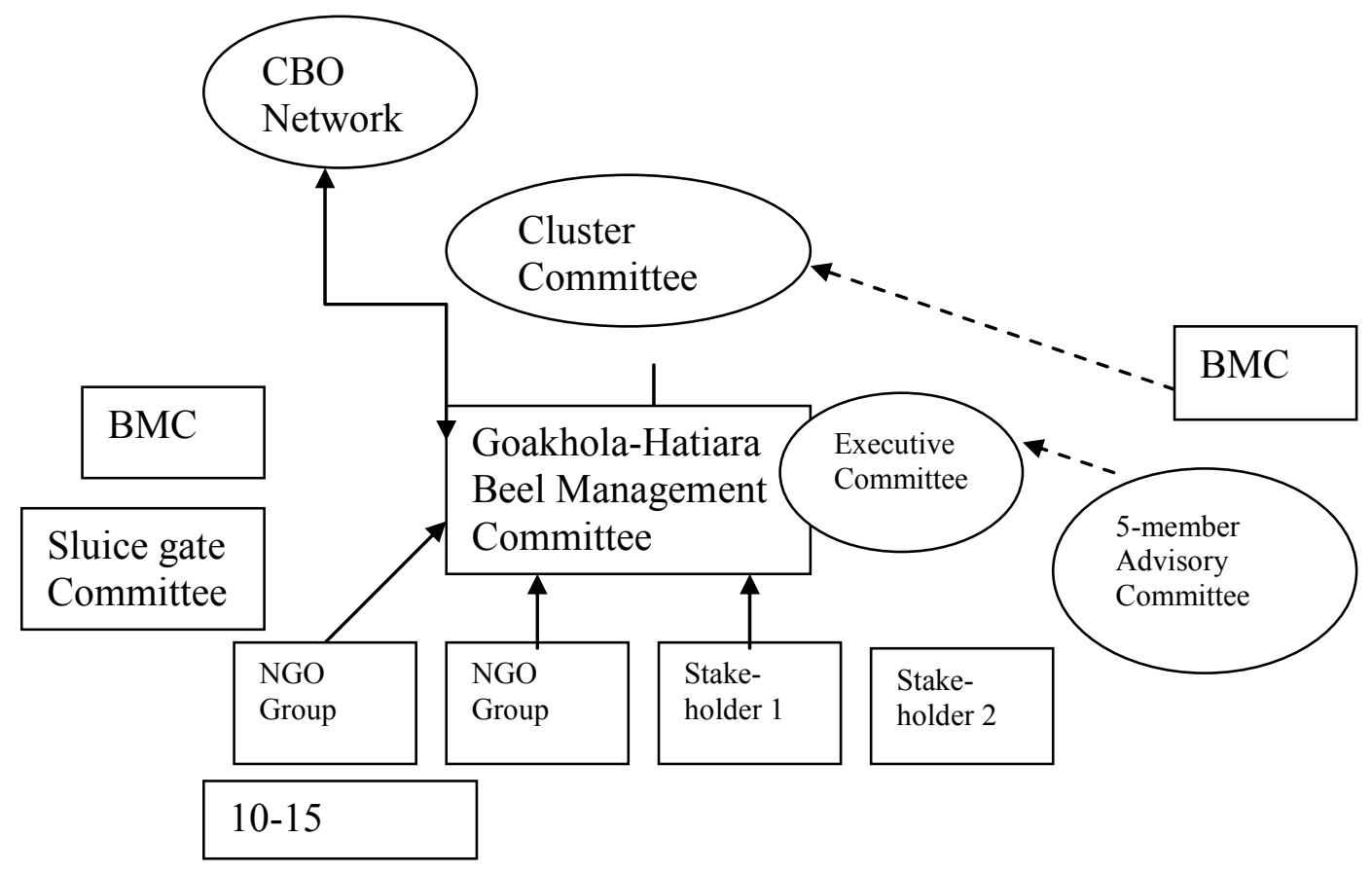




\section{IMPACT OF FISHERIES INSTITUTIONS IN CASE STUDY LOCATIONS}

In this section we review impacts that may be associated with the CBFM institutions developed in the three case study sites, wherever possible distinguishing men and women's opinions of possible impacts, but also considering overall changes and differences between the sites since each represents a different extent of women's and men's involvement in the resource management CBOs (BMCs and additionally the IFM committees in Goakhola and Maliate). We consider here: men and women's perceived problems, outcomes and trends in the fishery, and participants' assessments of institutional arrangements and their effectiveness.

\section{Perceived problems and issues}

There is some evidence that the problems and issues prioritized by men and women differ and this could have a bearing on collective action. However, problem censuses conducted separtely with men and women at different times and then consolidated indicate that the differences are greater between sites than between men and women (Table 4). In both Goakhola-Hatiara and Maliate, 70-90 percent of the main problems identified related to common pool natural resources - fish, surface water, floods and other aquatic resources, while the remaining problems identified were mainly related to private natural resources (low crop prices, for example). In Shuluar, only 25 percent of women's priority problems related to common pool natural resources, and 60 percent were not natural resource related, while for the men 44 percent of their priority problems were common pool natural resource related and 31 percent were not natural resource related. 
The differences appear to directly relate to the extent to which women and men actively collect common pool resources to support their livelihoods. For example, in the Muslim community of Shuluar mostly men fish and collect other aquatic resources and ranked these areas as high priorities but few women use wetland resources and they ranked poor communications and public services as their main problems). The differences also reflect the extent to which the local societies are concerned for the commons. The Hindu communities appear to have a greater concern for common resource problems even though the aquatic environments and status of natural resources were similar in all three sites). The lesser concern of the men over the aquatic resources appeared to be evident from the record of their attendance in monthly meetings and immediate decisionmaking. Despite this apparent difference in local priorities between men and women, the CBO in Shuluar has adopted some of the same interventions, such as fish sanctuaries, as in the other beels. In addition to differences in types of problems identified, there is a difference in the number of problems identified (10 for women, 16 for men) in Shuluar. The reason may be that women participants have limited knowledge about problems outside of their own sphere. Their exposure to issues outside the home is non-existent. 
Table 4--Ranking of problems as part of participatory planning by landless men and women

\begin{tabular}{|c|c|c|c|c|c|c|}
\hline \multirow[t]{2}{*}{ Problem } & \multicolumn{2}{|l|}{ Goakhola } & \multicolumn{2}{|c|}{ Maliate } & \multicolumn{2}{|r|}{ Shuluar } \\
\hline & Women & Men & Women & Men & Women & Men \\
\hline Natural fish declining & 1 & 1 & 1 & 1 & 1 & 1 \\
\hline Lack of safe drinking water & & & & & 2 & 6 \\
\hline Water logging & 10 & 2 & & & & 3 \\
\hline Siltation of canal & 3 & 9 & 2 & 8 & & 3 \\
\hline High cost of cultivation & & 4 & 9 & & & 5 \\
\hline Snail /aquatic plants declining & 2 & 10 & 3 & & & 8 \\
\hline Lack of grazing land- few livestock & 4 & 8 & 4 & 7 & & 8 \\
\hline Low prices of agricultural commodity & & & 10 & 6 & & 10 \\
\hline $\begin{array}{l}\text { Encroachment of khas land by } \\
\text { farmers }\end{array}$ & & & & & & 10 \\
\hline Fruit trees declining & & & & & 7 & 9 \\
\hline Water pollution & 9 & & & & 2 & 8 \\
\hline Flood & 5 & & & & 8 & \\
\hline Bad road communication & & & & & 4 & 2 \\
\hline
\end{tabular}


Table 4--Ranking of problems as part of participatory planning by landless men and women (continued)

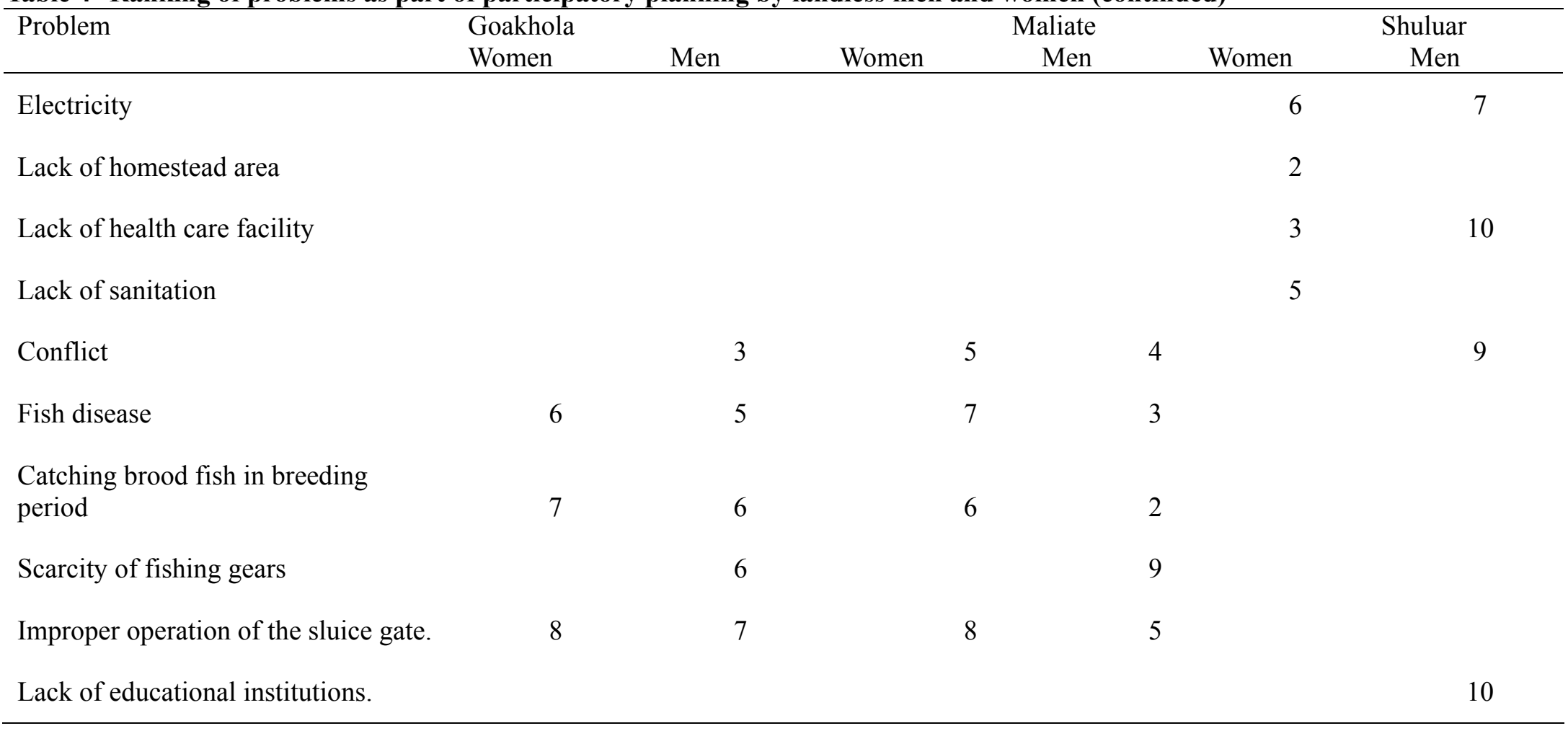


Table 4--Ranking of problems as part of participatory planning by landless men and women

\begin{tabular}{|c|c|c|c|c|c|c|c|}
\hline \multirow[t]{2}{*}{ Problem } & \multicolumn{2}{|l|}{ Goakhola } & \multicolumn{3}{|c|}{ Maliate } & & \multirow{2}{*}{$\begin{aligned} \text { Shuluar } \\
\text { Men }\end{aligned}$} \\
\hline & Women & Men & Women & Men & & Women & \\
\hline Number of problems & 10 & 11 & & 10 & 9 & 10 & 16 \\
\hline $\begin{array}{l}\text { Number of common problems (both } \\
\text { for men and women) }\end{array}$ & 8 & & & 8 & & 7 & \\
\hline $\begin{array}{l}\text { Common pool natural resource } \\
\text { related }\end{array}$ & 9 & 8 & & 7 & 6 & 2 & 7 \\
\hline Private natural resource related & 0 & 2 & & 2 & 2 & 2 & 4 \\
\hline Non-natural resource related & 1 & 1 & & 1 & 1 & 6 & 5 \\
\hline
\end{tabular}

Source: PAPD in Shuluar - July 2002; Maliate - February 2004; Goakhola-Hatiara - July 2003 
In each focus group discussion about 15-16 persons were in the session. Separate sessions were held with each stakeholder category, but only men and women from the landless/poor category are shown here for comparability. In Shuluar this was immediately before forming the $\mathrm{BMC}$, in Maliate this was two years after forming the $\mathrm{BMC}$, and in Goakhola this was immediately before forming the IFM committee but six years after forming the BMC under CBFM.

\section{Outcomes for fisheries}

The general resource management activities and actions in all three case study sites are similar. The BMCs protect fish in the dry season in some deep ditches (small sanctuaries), and they declared the early monsoon season closed for fishing. As a result some scarce fish species have been restored. However, the impact and the processes are different. In Shuluar, only men benefit economically from fisheries management, but in the other two beels both men and women fish and collect other aquatic resources and now earn more than before.

\section{Management actions}

In Goakhola-Hatiara Beel, from the dry season of 1997-98 to the dry season of 200102 usually five kuas were rented and protected as sanctuaries each year. The individual kuas differed between years, as the BMC chose those whose owners were willing to rent them and which were thought to have a good fish population. No fishing was allowed in those kuas. The average kua is about 7.8 decimals in area, indicating a total sanctuary area of about 0.16 ha out of a total area of kuas of about 2.9 ha. In 2003 to 2005 no kuas were rented as sanctuaries. The BMC designated the whole of the khal as a dry season sanctuary up to and including the early monsoon, but allowed fishing there in the monsoon and post monsoon. 
The area of the khal in the dry season is about 1-1.5 ha. In the 2004-05 dry season the BMC excavated some plots that were bought by CBFM-2 project to create permanent sanctuary kuas, but these will not have any impact on fish catches until 2006 since they were dry for excavation in the dry season of 2004-2005.

In Maliate and Shuluar Beels, the same strategy was adopted: from the dry season of 2002-03 some kuas were rented as sanctuaries and were protected, and in 2004-05 some permanent sanctuary kuas were created. Similarly in all three sites each year the first three months of the Bangla year (Baishak, Jaistha and Ashar) - mid April to mid-July - have been declared by the BMC as a closed season with no fishing permitted in the beel or khal.

\section{Fish catches}

The data on fish catches comprises two parts: catches from various gear (mostly gill nets, traps, hook and line, and cast nets in years of higher water levels, plus a few lift nets located in the khals); and the catch from the kuas. Data are only available for different gears for a series of years for Goakhola, which indicate higher catches from 1998 onwards (a year after the start of conservation measures), but also shows exceptionally high catches in 200102 (mostly from lift nets) that were not continued (Figure 4). 


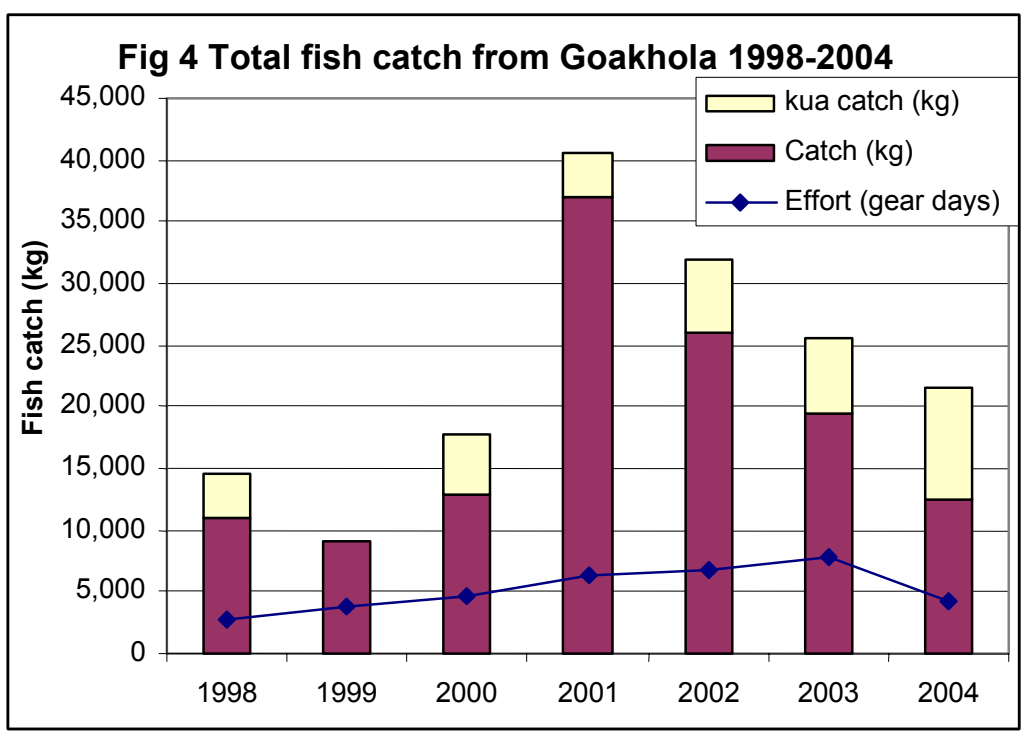

Overall, there do appear to be gains from improved fishery management, (at least in Goakhola-Hatiara Beel, which has a longer series of data), which translate into higher fish catches, although the catch has fluctuated between years (Figure 4). This benefit reaches both men and women there, since women also catch fish and can show a return from their involvement in fishery management through better fish consumption and a supplementary source of income.

A major part of the fish catch, usually about a quarter of the total catch, comes from the many kuas (ditches) in the floodplain of Goakhola (and also in Maliate) Beel. In Goakhola before the introduction of IFM, kua catches fluctuated around $50 \mathrm{~kg}$ per kua (water area of just over seven decimals). Kua catches increased in 2002 in line with the increase in fish population and catches experienced from 2001 (the kua harvest takes place in the first months of the year and involves fish left over in the ditches from the previous monsoon). This increase continued up to 2004; in 2005 to conserve some fish kuas were harvested only one or 
two times and a few were left un-fished, but the catch remained high (Table 5). The trend was similar in Maliate, but in Shuluar there was a notable gain in kua harvests in 2005, suggesting that conservation measures there have been effective, but that the benefits may go more to owners of ditches who tend to be better off than many of the other households involved in open water fishing. 
Table 5--Fish catch and returns from kuas in 2003-2005

\begin{tabular}{|c|c|c|c|c|c|c|c|c|c|}
\hline \multirow[t]{2}{*}{ Year } & \multicolumn{3}{|c|}{ Goakhola Beel } & \multicolumn{3}{|c|}{ Maliate Beel } & \multicolumn{3}{|c|}{ Soluar Beel } \\
\hline & $\begin{array}{r}\text { No. } \\
\text { of kuas } \\
\text { fished }\end{array}$ & $\begin{array}{r}\text { Catch } \\
(\mathrm{kg})\end{array}$ & $\begin{array}{r}\text { Mean } \\
(\mathrm{kg} / \mathrm{kua})\end{array}$ & $\begin{array}{r}\text { No. } \\
\text { of kuas } \\
\text { fished }\end{array}$ & $\begin{array}{r}\text { Catch } \\
(\mathrm{kg})\end{array}$ & $\begin{array}{r}\text { Mean } \\
(\mathrm{kg} / \mathrm{kua})\end{array}$ & $\begin{array}{r}\text { No. } \\
\text { of kuas } \\
\text { fished }\end{array}$ & $\begin{array}{r}\text { Catch } \\
(\mathrm{kg})\end{array}$ & $\begin{array}{r}\text { Mean } \\
(\mathrm{kg} / \mathrm{kua})\end{array}$ \\
\hline 2003 & 87 & 6,097 & 67 & 39 & 2,583 & 66 & 49 & 4,740 & 97 \\
\hline 2004 & 87 & 9,100 & 100 & 40 & 3,088 & 74 & 52 & 5,736 & 110 \\
\hline 2005 & 83 & 6,643 & 73 & 36 & 2,688 & 64 & 60 & 12,106 & 202 \\
\hline
\end{tabular}

Source: Census of kuas and reported catches according to owners 


\section{Fish diversity}

Fish species diversity appears to have increased in all three sites as a result of these conservation measures: in Goakhola Hatiara there are eight years of detailed catch monitoring records indicating that the number of species recorded per year was 28 between 1997 and 1999 and rose to 34 per year between 2000-2004; in Shuluar the number of species caught more than doubled (from 23 to 47) between 2002 and 2004; and in Maliate 21 were caught in 2003 and 36 in 2004. However, the diversity of fish consumed has not changed over the same periods, in part because households buy fish that have been caught in any of the local floodplain beels and appear in the local markets, including cultivated fish. For Goakhola, there was sufficient data from detailed monitoring of a sample of households to review changes in wild caught fish from the beel in the diet, which suggest (after allowing for changes in the survey method in $2002^{4}$ ) that species diversity fluctuates (from 35-45 wild caught species per year during 1997-2002 to 28-29 species in 2003-2004 when consumption was monitored on half the number of days). Nevertheless discussion with the communities indicates that some scarce floodplain species, notably meni Nandus nandus and pabda Ompok pabda have recovered since CBFM activities started.

The fish species count in Maliate Beel demonstrates that women are just as capable as men in protecting fish. In both of the beels where women are involved in the CBOs and in resource management (Goakhola Hatiara and Maliate), they have maintained sanctuaries and guarded them in the day time, and have been helped by men (husbands) to guard the

\footnotetext{
${ }^{4}$ The size of the sample of households monitored for their fish consumption changed to 30 households in 2002 and onwards; in previous years it was 60 households.
} 
sanctuaries at night. Moreover, much of the pressure to ensure community compliance with sanctuaries and fishing rules comes from women in the homestead who control what is cooked, discuss the issue in group meetings, and (in the same two beels) decide to catch or not catch fish by their own hands.

\section{Involvement of men and women in resource use and their assessment of institutions}

\section{Context, resource use and incomes}

A household survey was undertaken in August 2005 in which men and women from the same households were interviewed separately, mainly to assess their opinions about the institutional arrangements for resource management and perceived changes over the last three years. The sample covered the same households (30 each in Goakhola and Maliate and 50 in

Shuluar) that had been surveyed earlier. However, an additional sample of farming households was surveyed and, where appropriate, data from this larger sample are reported.

Education levels differ between men and women and between women in all the beels (Table 6). The women in Maliate Beel are more educated than the women in Goakhola and Shuluar and even better educated than men in the same beel. This may be one of the reasons for women assuming the lead positions in all the floodplain resource management institutions in that area. One reason for, and component of, the subordinate position of the women in Shuluar Beel is perhaps lack of education and awareness. However, for the last few years girls have received grants and wheat from the government for attending school up to the secondary level so their status may change over time as more parents send their daughters to school. 
Table 6--Education level of male and female respondents (\%) in 2005.

\begin{tabular}{lcccccc}
\hline Education level & \multicolumn{2}{c}{ Goakhola-Hatiara } & \multicolumn{2}{c}{ Maliate } & Shuluar \\
\cline { 2 - 7 } & Male & Female & Male & Female & Male & Female \\
\hline None & 13 & 19 & 36 & 12 & 46 & 46 \\
Can sign only & 21 & 19 & 17 & 17 & 26 & 32 \\
Primary only & 27 & 44 & 21 & 26 & 14 & 12 \\
Secondary completed & 5 & 0 & 7 & 5 & 4 & 0 \\
$\begin{array}{l}\text { Higher (including } \\
\text { degrees) }\end{array}$ & 34 & 18 & 19 & 40 & 10 & 0 \\
Total response & 62 & 62 & 42 & 42 & 50 & 50 \\
\hline
\end{tabular}

Respondents were heads of household (mostly men) and spouse/senior person of the opposite gender in the household

None of the sample respondents are professional fishers in Goakhola-Hatiara, and there are no known full time fishers in this community (Table 7). Virtually all households there have some farmland, and the fishing period is short, with a lack of other sources of fish during the rest of the year. The river near Goakhola-Hatiara and Maliate beels does not hold a large population of fish. The men are mostly involved in part-time fishing. They use traps and gill nets after the monsoon and fish for both food and income. The women are involved in fishing mostly for food; some widows and women from poor households sell fish to make money. This picture is very different from other parts of Bangladesh where women never fish in open water. In Shuluar Beel women do not fish except for a few women from very poor families who fish by hand when water recedes in November-December. In all the beels women only use rod and line or hand to fish. 
Table 7-- Involvement of respondents in fishing (\%) in 2005.

\begin{tabular}{|c|c|c|c|c|c|c|}
\hline \multirow{2}{*}{$\begin{array}{l}\text { Fishing } \\
\text { involvement }\end{array}$} & \multicolumn{3}{|c|}{ Goakhola- } & \multicolumn{2}{|l|}{ Maliate } & \multirow{2}{*}{$\begin{array}{l}\text { Shuluar } \\
\text { Female } \\
\end{array}$} \\
\hline & Male & Female & Male & Female & Male & \\
\hline Professional & 0 & 0 & 5 & 0 & 12 & 0 \\
\hline Part-time & 32 & 27 & 10 & 12 & 34 & 2 \\
\hline Subsistence & 50 & 37 & 62 & 36 & 26 & 0 \\
\hline Never fished & 18 & 35 & 24 & 52 & 28 & 98 \\
\hline $\begin{array}{l}\text { Total } \\
\text { respondents }\end{array}$ & 62 & 62 & 42 & 42 & 50 & 50 \\
\hline
\end{tabular}

Respondents were head of household (mostly men) and spouse/senior person of opposite sex in household

The income in all three beels from harvesting different aquatic resources was quite substantial considering that these common pool resources are only available during the monsoon and provide an extra income (Table 8). It was reported that due to conservation of fish during the dry season, in the wet season the amount and value of fish harvested in open water and in private ditches increased. Benefits are not distributed evenly in Shuluar Beel where landowners are now preventing other people from fishing in their lands. However, they are not harvesting fish by dewatering. The findings are consistent with the labor use in collecting aquatic resources discussed earlier: men mainly fish, while women in Goakhola and Maliate obtain over half of the value of aquatic resources they collect from plants and snails. Moreover, women contribute almost half of total household income derived from floodplain common pool resources in those two beels, but very little in Shuluar. 
Table 8-- Annual income /value of natural resources (Tk) collected in 2003 and 2004

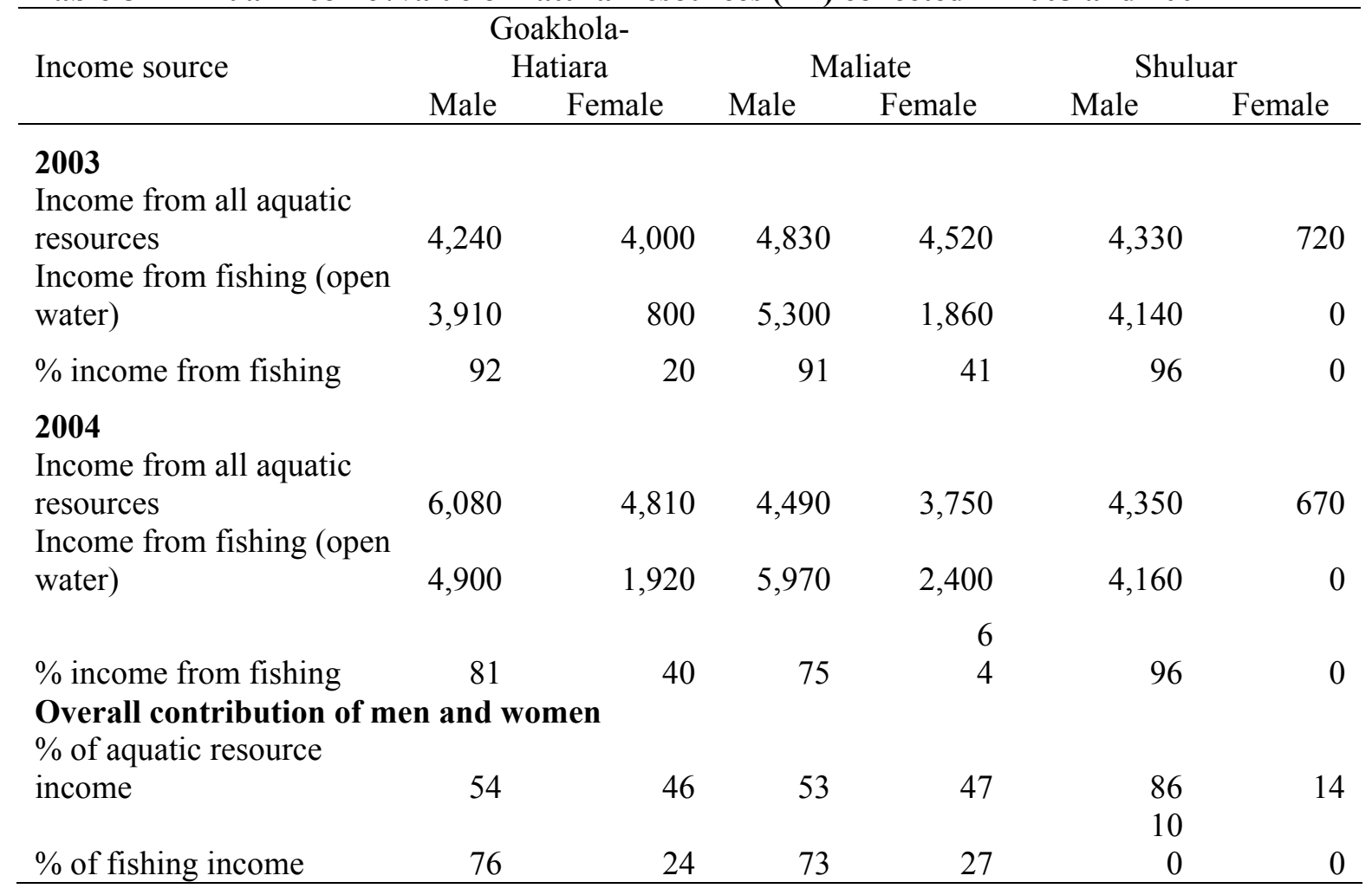

Figures are in Taka: US\$ 1=Tk.62 in early 2005

Source: household aquatic resource collection survey

Separate data for 2004-05 (Table 9) showed similar average household incomes from aquatic resources in Goakhola and Maliate Beels to the figures in Table 8, but rather higher average incomes from fish in Shuluar. Average household incomes in Goakhola in 2004-05 were double those in Shuluar, and 75 percent higher than in Maliate. However, the main source of income for Goakhola-Hatiara is government service and business, and not from the beel itself. Only about 25-30 percent of average household income comes from own-farm cultivation in all three beels. Daily wage income is low in Goakhola compared to other sources, but a substantial amount comes from daily sources in Maliate. Aquatic common pool resources contributed 16 percent of household income in Maliate and Shuluar, but only 6 percent in Goakhola due to the high non-beel related incomes there. 
Table 9--Household income from different sources (Tk per household) in 2004-2005

\begin{tabular}{|c|c|c|c|}
\hline Income source & Goakhola $(\mathrm{N}=30)$ & Maliate $(\mathrm{N}=30)$ & Shuluar $(\mathrm{N}=50)$ \\
\hline Daily (e.g. labor) & 19,060 & 23,990 & 17,930 \\
\hline Annual (e.g. business) & 59,590 & 9,260 & 10,480 \\
\hline Agriculture & 22,800 & 17,250 & 15,180 \\
\hline Aquatic resources & 7,060 & 10,630 & 8,580 \\
\hline All & 108,500 & 61,130 & 52,160 \\
\hline
\end{tabular}

Source: household impact survey

US\$ $1=$ Tk.62 in early 2005

As might be expected, given their dominance over income earning activities, men borrowed and sold assets more than women in 2004-05. But it is notable that even in Shuluar 21 percent of borrowing and asset sales were by women (Table 10), as in Shuluar they receive some loans from the NGO. Men in general in all three sites had wider sources for borrowing, such as banks and money lenders. In Maliate Beel, in addition to belonging to the NGO groups, women have their own revolving loan fund from which they can borrow money which may help explain the higher percentage (48 percent) of total loans and asset sales taken by women, and the relatively higher ratio of borrowing and asset sales to income. These women manage the amount by themselves. In Goakhola the IFM committee also has a fund but the amount is too small to use as revolving loan fund. However, in the 2004-05 rabi (dry) season they requested and received seasonal loans from Banchte Shekha for rabi crop cultivation. This was a big help to them. 
Table 10--Value of credit and major asset sales (Tk per household) by gender of borrower in year 2004-2005

\begin{tabular}{lccc}
\hline & Goakhola & Maliate & Shuluar \\
\hline Men & 18,962 & 16,236 & 10,350 \\
Women & 9,357 & 15,250 & 2,824 \\
\hline
\end{tabular}

\section{Organization membership and self assessments}

In Goakhola-Hatiara and Maliate Beels, women's involvement in local organizations is higher than in Shuluar Beel (Table 11). In Shuluar the sample women are only involved in NGO groups. The apparently low membership of women in different organizations in Maliate Beel is because few of the women from the BMC were included in the sample. By comparison the sample from Goakhola includes women who are active in the CBM and IFM committees as well as school committees and NGO groups. The results are consistent with information from focus groups - that women in Goakhola (but also Maliate) are more involved in local institutions outside of those created for fishery and floodplain management. 
Table 11--Organizational membership (percentage of respondents, multiple responses/memberships possible) in 2005

\begin{tabular}{|c|c|c|c|c|c|c|}
\hline \multirow[t]{2}{*}{ Institution } & \multicolumn{2}{|c|}{ Goakhola-Hatiara } & \multicolumn{2}{|c|}{ Maliate } & \multicolumn{2}{|c|}{ Shuluar } \\
\hline & Male & Female & Male & Female & Male & Female \\
\hline $\begin{array}{l}\text { Beel Management } \\
\text { Committee }\end{array}$ & 13 & 11 & 4 & 2 & 17 & \\
\hline $\begin{array}{l}\text { Mosque/temple } \\
\text { committee }\end{array}$ & 10 & 2 & 4 & & 15 & . \\
\hline IFM committee & 6 & 9 & 2 & 6 & & . \\
\hline Sluice gate committee & 6 & & 2 & & & . \\
\hline IPM group & 6 & 2 & 4 & & 2 & . \\
\hline School committee & & 6 & 2 & & & \\
\hline $\begin{array}{l}\text { NGO group/ } \\
\text { cooperative (general or } \\
\text { women's) }\end{array}$ & 2 & 17 & 4 & 21 & & 25 \\
\hline $\begin{array}{l}\% \text { of respondents } \\
\text { belonging to some } \\
\text { local institution }\end{array}$ & 44 & 45 & 23 & 30 & 33 & 25 \\
\hline
\end{tabular}

Respondents were head of household (mostly men) and spouse/senior person of opposite gender in household

When separate focus groups were held to assess the level of social capital in their community using five indicators and scales, the scores differed between men and women and between sites (Table 12). In Goakhola and Maliate Beels, all indicators were much higher than in Shuluar except for conflict, indicating a much higher general level of trust and cooperation in those beels. Since this assessment was made when the BMCs in Maliate and Shuluar were being formed, this difference in levels of social capital helps to explain differences in the effectiveness of the BMCs, including greater problems in Shuluar. The respondents thought that there was scope for improvement and mentioned that difficulties over access to water bodies for the poor was one reason that social capital needs to be improved. In general, men scored all of the indicators lower or the same as women in all three sites, indicating that women may see their communities as more harmonious than do men. 
Table 12-- Self assessments of present level of social capital indicators in 2002 (scale 110)

\begin{tabular}{lcccccc}
\hline \multirow{2}{*}{ Indicator } & \multicolumn{2}{c}{ Goakhola Beel } & \multicolumn{2}{c}{ Maliate Beel } & \multicolumn{2}{c}{ Shuluar Beel } \\
\cline { 2 - 7 } & Male & Female & Male & Female & Male & Female \\
\hline Trust & +5 & +7 & +7 & +8 & +1 & +4 \\
Unity & +5 & +9 & +7 & +9 & +2 & +4 \\
Empathy & +5 & +5 & +8 & +8 & +2 & +5 \\
Cooperation & +7 & +8 & +10 & +10 & +2 & +3 \\
Conflict & +10 & +10 & +8 & +10 & +8 & +8 \\
\hline
\end{tabular}

Source: PRA focus groups held in 2002

In the household survey in August 2005, opinions were taken in response to a range of statements related to collective action, fishery and floodplain resource management issues (Appendix 1). The responses indicate high levels of agreement that people could participate now in managing common resources, and that poorer households were benefiting. Notably, less than half of the women think that their voice is heard in beel management decisions in the beels with mixed men and women in the BMCs such as Goakhola-Hatiara, but in Shuluar only 8 percent of women think their voice is heard. Similarly, knowledge of women in Shuluar regarding improved floodplain management is less. However, all respondents accept fishing related rules. In addition, some impacts of the IFM project are apparent in Goakhola where there has been less increase in groundwater irrigation through shallow tubewells (STW), and more respondents recognize the scope to limit water quality problems from jute retting (which have been addressed by the IFM project through training and demonstrations there). 
Men and women from the households were asked separately to score the present situation and that of three years before for a range of indicators for community based management of these floodplains. A self-weighting ladder scale was used ranging from 1 (worst imaginable case) to 10 (best imaginable case). The results (Appendix 2) indicate that in Goakhola participation and influence on decisions both at community level and regarding the fishery has increased significantly for men and women, but was scored significantly higher by men than their spouses. By comparison in Maliate, with the all-women BMC, only women reported significant increases in participation and influence and mainly with regard to the fishery and IFM. In Shuluar, only men reported significant increases in participation, and they also have significantly higher scores for general participation and influence then their wives, unlike in Maliate.

Respondents believe that decisionmaking on fishing rules, access and resource management have all in general improved significantly. In Goakhola-Hatiara, despite having the longest established CBFM institutions and activities, both men and women reported similar significant improvements and the scores did not differ much from the other two beels. In Maliate, where women take the beel management decisions, they perceived more significant improvements than men, and reported an increase in fair access that was significantly greater then for men, which presumably reflects their increasing role in beel management since 2002 and the formation of their BMC, and their voluntary formation of a committee for IFM. However, in Shuluar Beel the changes in scores were contradictory: men and women gave significantly higher scores in 2005 for rule making, active fishery management and compliance, yet men reported a decline in fair access and both men and women regard the overall condition of the floodplain to have become worse. The reasons for 
this are not clear, but considering the timing of the survey in August 2005 when relatively more jute had been grown and there were problems with the quality of water in the beels and fish kills, the opinions may have been influenced by this. Although slightly more jute was also grown in Goakhola and Maliate, the increase was less and there the IFM project facilitated training and piloting of less harmful retting techniques and farmers avoided retting so much within the beel.

\section{Assessment of beel management committees}

The most revealing evidence of differences that may affect the way that the CBOs function came from discussing with the committee members (i.e. women and men in Goakhola, women only in Maliate, and men only in Shuluar) what their criteria were for successful integrated floodplain resource management. The committees that included women identified more criteria (16 for Goakhola, 20 for Maliate), compared with just 10 in Shuluar, and the criteria differed (Appendix 3). All three agreed that strong leadership was the most important factor for success, but after that the CBOs with women members rated establishing the authority (legitimacy) of the CBO for resource management next (and that they had achieved this), while the men-only CBO emphasized establishing a fund for future activities (which they had yet to achieve).

The women-only CBO placed as $3^{\text {rd }}, 4^{\text {th }}$ and $5^{\text {th }}$ participatory decisionmaking, representation of different stakeholders in decisions and having a management plan (and said they had achieved all of these). The mixed CBO emphasized social responsibility in the community, awareness among all community members and timely implementation of activities (and was partially satisfied it had achieved these). The all male CBO emphasized 
cooperation and respect among members of the committee, establishing community rules, and compliance with the rules (and was also partially satisfied). Thus the women only CBO places greater value on participatory processes leading to its plans, the mixed CBO on whole community action and norms, and the male only $\mathrm{CBO}$ on setting rules that it sees as in the interests of the community.

\section{CONCLUSIONS}

Although measuring impacts on fisheries and livelihoods from community based management initiatives is not easy and is compounded by variability between years, in all three communities both men and women recognize gains and improvements in the health of the resource, even where women did not have a role in decisionmaking. Consequently, the BMCs reported high acceptance and compliance with limits they set on resource use, although compliance was higher in the sites where women had a role in decisionmaking and men also were active decision makers (Goakhola) or where men advised and endorsed decisions (Maliate), than in the site where women played no role (Shuluar). In each case, the number of conflicts decreased over time and the BMCs have been recognized, and their plans accepted, by the communities which now follow rules set by the BMCs. The number of rules introduced by the committee increased during the study for those involving women - Goakhola-Hatiara and Maliate Beels. The Maliate BMC has been more adaptable, slowly introducing rules and adjusting the rules between years. For example, if the members see small sized fish or new species in the closed season they have prolonged the closed period through motivational work with the community. They tell the community that the fish price will be higher after a month 
when fish size increases. The women usually take the initiative to tell each family and they convince family members to wait to catch fish. These initiatives are spontaneous and the community appreciates these initiatives.

Ability to establish community based organizations where women play an active or leading role is influenced by local community norms and culture and the acceptance of women's involvement in economic activities outside the home. In the study area, this is greater among Hindu communities than in the Muslim dominated area where women do not normally have much, if any, say in public affairs. This is also affected by education levels - in Shuluar few women have attended school whereas the average education level of women and men in the other two beels is almost equal. There appears to be a compounding effect of education, social norms, economic activity and mobility which constrain or permit women to have equal roles with men for natural resource management.

The status and recognition given to women by the local community and leaders reflects this experience and although hard to quantify, was highlighted by women in focus group discussions. In Goakhola and Maliate, women reported increasing recognition of their voices and willingness to listen to their opinions, which in turn led to increased willingness of the women to join local institutions and greater acceptance by men of their decision to do so. For example, the female BMC members reported also belonging to several other local committees and institutions, and this was also shown by sample surveys. By comparison, in Shuluar Beel women have not been given any place in the BMC by the men, who do not recognize the fact that some women do actually depend on using non-fish aquatic resources. Consequently, women have no power or role in decisionmaking in Shuluar Beel, and although 
these women now recognize the value to the community of fishery related rules, the BMC has not addressed many of their concerns.

It is also evident that facilitation by an NGO that focuses solely on women's development, as is the case in all three case studies, is not sufficient to ensure women's participation in decisionmaking and community institutions because their participation is also affected by cultural norms and the extent to which women and men directly use the resources. Hence it is important for those planning to support and facilitate community based management of natural resources to follow processes that include women and help both men and women recognize the uses, opinions and relevance of those resources as they relate to women (as in participatory planning in the cases considered here). Where local social norms and culture limit the public voice of women, women cannot be expected to take a lead in resource management and will need a long term plan for developing their capacity and changing men's opinions. However, it is clear that at least in the context of Bangladesh floodplains, women-led community organizations can improve fishery management, and involving women in fishery management appears to be associated with greater community wide acceptance of management rules and reduced conflict. Policy should aim for community-wide participation including an active role for women. 


\section{REFERENCES}

Ali, M.Y. 1997. Fish, water and people. Dhaka: University Press Ltd.

BBS. 1996. Statistical yearbook of Bangladesh 1995. Dhaka, Bangladesh: Bangladesh Bureau of Statistics.

BBS. 1997. Statistical yearbook of Bangladesh 1996. Dhaka, Bangladesh: Bangladesh Bureau of Statistics.

BBS. 1998. Statistical yearbook of Bangladesh 1997. Dhaka, Bangladesh: Bangladesh Bureau of Statistics.

Coleman, J.M. 1968. Brahmaputra river: Channel processes and sedimentation. Sedimentary Geology 3: 129-239.

FAO, 1988. Agro-ecological regions of Bangladesh. Rome: Food and Agriculture Organization.

FAP 4. 1993. Southwest area water resources management study. Final Report. Dhaka: Flood Plan Coordination Organisation and Bangladesh Water Development Board (Report prepared by Sir William Halcrow \& Partners in association with Danish Hydraulic Institute, Engineering and Planning Consultants, and Sthapati Sangstad).

FAP 16. 1995. Potential impacts of flood control on the biological diversity and nutritional vale of subsistence fisheries in Bangladesh. Dhaka: Flood Action Plan 16 Environmental Study, Flood Plan Coordination Organisation, Ministry of Water Resources (Report prepared by Irrigation Support Project for Asia and the Near East).

Huda, N. 1989. Flood control proposal for the major river systems of Bangladesh. In Flood in Bangladesh, ed. Ahmad, M. Dhaka, Bangladesh: Community Development Library.

Hughes, R., Adnan, S. and Dalal-Clayton, B. 1994. Floodplains or flood plans? London: International Institute for Environment and Development, and Research and Advisory Services.

Karim, A. 1993. Freshwater wetlands of Bangladesh: Status and issues. In Freshwater wetlands of Bangladesh: Issues and approaches. Dhaka, Bangladesh: IUCN.

Muir, J. (ed.) 2003. Fisheries Sector Review and Future Development: theme study: economic performance. Dhaka, Bangladesh: World Bank, Danida, USAID, FAO and DFID.

MWR. 1999. National water policy. Dhaka, Bangladesh: Government of People's Republic of Bangladesh, Ministry of Water Resources. 
NCS, 1991. National conservation strategy. Dhaka, Bangladesh: Government of People's Republic of Bangladesh, Department of Environment.

Rahman, A. K. A. 1989. Freshwater fish of Bangladesh. Dhaka, Bangladesh: Dhaka University Press.

Sultana, P., Thompson, P., Ahmed, H, and Hossain, A. 2005. Better options for integrated floodplain management in Bangladesh: Uptake pPromotion piloting of IFM options: Narail site. Dhaka, Bangladesh: Centre for Natural Resource Studies and WorldFish Center.

Thompson, P.M., Sultana, P. and Islam, N. 2003. Lessons from community based management of floodplain fisheries in Bangladesh. Journal of Environmental Management 69(3): 307-321.

United Nations. 2000. The Common country assessment: Bangladesh. Dhaka, Bangladesh: University Press Ltd.

World Bank 1998. Bangladesh 2020. Dhaka, Bangladesh: University Press Ltd.

WorldFish Center. 2003. Community based Fisheries management project phase 2 Annual report 2002. Dhaka, Bangladesh: WorldFish Center. 


\section{APPENDICES}

\begin{tabular}{|c|c|c|c|c|c|c|}
\hline \multirow[t]{2}{*}{ Indicator/statement } & \multicolumn{2}{|c|}{ Goakhola Hatiara } & \multicolumn{2}{|c|}{ Maliate Beel } & \multicolumn{2}{|c|}{ Shuluar Beel } \\
\hline & Male & Female & Male & Female & Male & Female \\
\hline $\begin{array}{l}\text { a) Mean score for opinions a (Number of } \\
\text { respondents) }\end{array}$ & 30 & 30 & 30 & 30 & 50 & 50 \\
\hline $\begin{array}{l}\text { Community people can participate in common } \\
\text { property resource management }\end{array}$ & 4.46 & 4.21 & $4.19 *$ & 3.74 & 3.62 & 3.43 \\
\hline My voice is heard in management & $3.82 *$ & 3.18 & 3.23 & 2.62 & $3.10^{* *}$ & 2.20 \\
\hline $\begin{array}{l}\text { I know how to improve livelihoods dependent on } \\
\text { floodplain }\end{array}$ & 3.82 & 3.79 & 3.96 & 3.78 & $3.57 *$ & 2.89 \\
\hline People should be able to fish wherever they like & 2.14 & 2.14 & 2.19 & 2.15 & 2.17 & 2.13 \\
\hline People should be able to use whatever gear they like & 2.07 & 2.18 & 1.89 & 2.19 & 2.02 & 2.19 \\
\hline Rule breaking is sometimes acceptable & 2.37 & 2.37 & 2.04 & 2.15 & 2.46 & 2.70 \\
\hline Small/marginal farmers are benefited from new crops & 4.14 & 4.21 & 3.85 & 4.00 & 4.04 & 3.85 \\
\hline $\begin{array}{l}\text { Agricultural laborers are better of now than } 3 \text { years } \\
\text { ago }\end{array}$ & 4.07 & 4.18 & 4.15 & 4.04 & 4.13 & 4.21 \\
\hline
\end{tabular}


Appendix 1--Responses to statements regarding community based management and integrated floodplain management (continued)

Jute retting can be modified to minimize any harm to the aquatic environment
4.11
3.96
3.96
3.80
3.47
3.70

Use of STW has increased in this area in the last 3

years

3.79

3.93

4.11

4.00

4.38

4.36

b) \% Agree or strongly agree (Number of respondents)

72

28

52

50

Community people can participate in common property resource management

I know how to improve livelihoods dependent on floodplain

People should be able to fish wherever they like

People should be able to use whatever gear they like 
Appendix 1--Responses to statements regarding community based management and integrated floodplain management (continued)

Jute retting can be modified to minimize any harm to the aquatic environment

90

79

85

58

Use of STW has increased in this area in the last 3 years

65

93

85

92

${ }^{a}$ scale: 5-Strongly agree, 1-Strongly disagree

* $\begin{aligned} & \text { Men } \\ & \text { Note wamen, paired t-test } \mathrm{p}<0,05\end{aligned}$ sample of farmers were asked to respond to the statements, these responses are included in the percentages but not in the statistical tests

Source: interview survey - respondents were head of household (mostly men) and spouse/senior person of opposite gender in household 
Appendix 2--Respondent assessments of changes in key indicators of community management of fishery assessed through comparison of mean scores in 2005 and 2002 (see appendix 2 footnotes below for 2002 details and explanation)

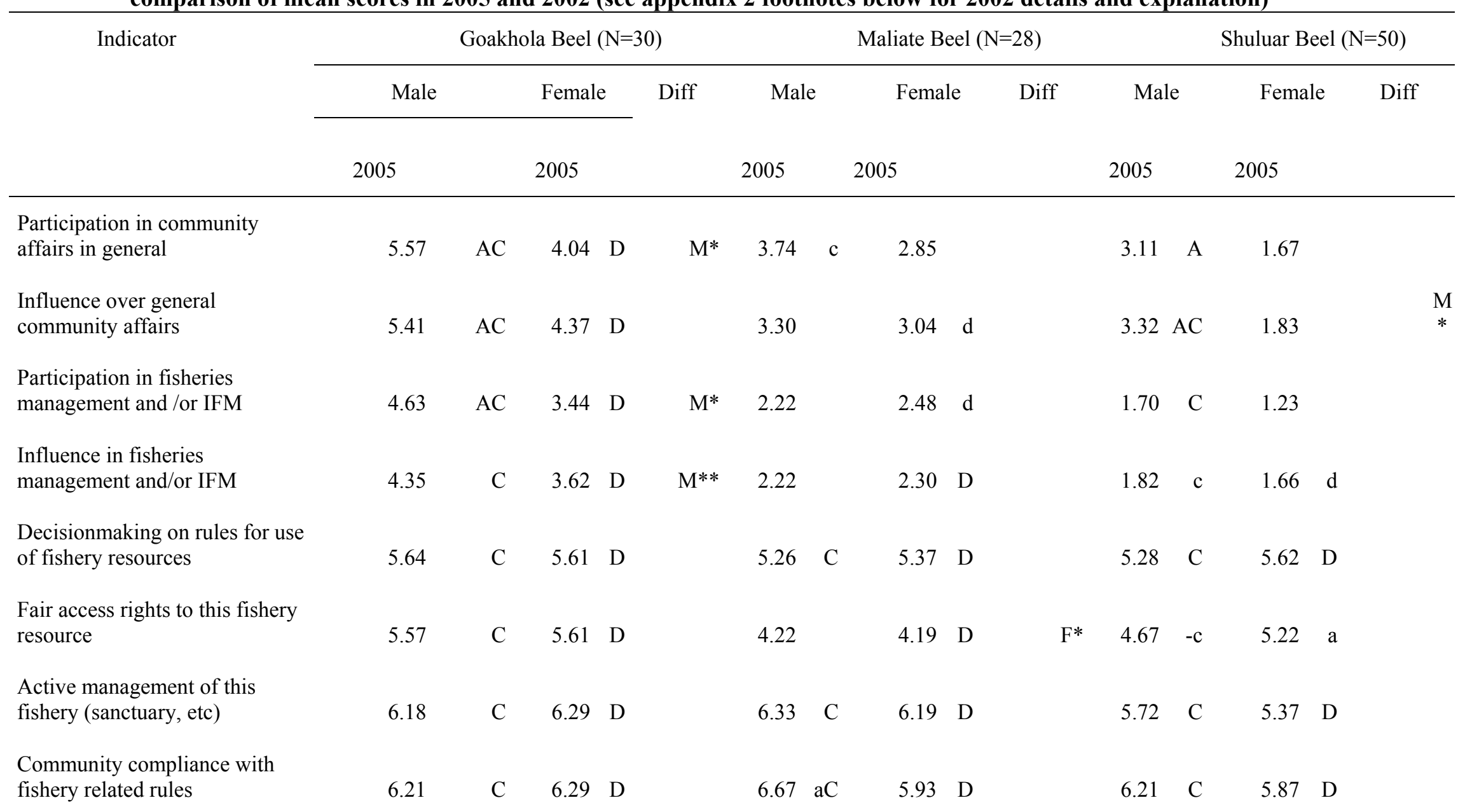


Appendix 2--Respondent assessments of changes in key indicators of community management of fishery assessed through comparison of mean scores in 2005 and 2002 (see appendix 2 footnotes below for 2002 details and explanation) (continued)

Overall well being of this

fishery/floodplain

6.07

5.86
$6.19 \mathrm{aC}$

$5.89 \mathrm{C}$

$5.93 \mathrm{C}$

$6.04 \mathrm{C}$
$4.49 \mathrm{C}$

5.85
$4.38-\mathrm{D}$

Although scores from 2005 and 2002 are compared in the statistical tests reported, the scores for 2002 are not shown in this table.

Indicators were scored by the respondents on a scale of 1-10 with 1 and 10 defined respectively as the worst and best conditions that the household could imagine for that indicator.

Paired t-tests:

Comparing male $\mathrm{v}$ female responses for 2005: $\mathrm{a}-\mathrm{p}<0.05, \mathrm{~A}-\mathrm{p}<0.01$, location of letter indicates gender giving higher score.

Comparing scoring for men in $2005 \mathrm{v} 2002$ : $\mathrm{c}-\mathrm{p}<0.05, \mathrm{C}-\mathrm{p}<0.01$ (negative indicates 2002 was significantly higher than 2005)

Comparing scoring for women in $2005 \mathrm{v} 2002$ : $\mathrm{d}-\mathrm{p}<0.05, \mathrm{D}-\mathrm{p}<0.01$ (negative indicates 2002 was significantly higher than 2005)

Diff $=$ comparing changes in scores $2002-05$ for men $v$ women: $M^{*}$ - male score increased more than women $p<0.05$, $M^{* *}-$ male score increased more than women $\mathrm{p}<0.01, \mathrm{~F}^{*}$ female score increased more than men $\mathrm{p}<0.05$.

Source: interview survey with random sample, respondents were head of household (mostly men) and spouse/senior person of opposite gender in same

household. Men or women were not willing to answer these questions in two of the Maliate Beel sample households. 
Appendix 3--Local stakeholder criteria for successful Integrated Floodplain Management

\begin{tabular}{|c|c|c|c|c|c|c|}
\hline \multirow[t]{2}{*}{ Success criteria } & \multicolumn{2}{|c|}{ Goakhola Beel } & \multicolumn{2}{|c|}{ Maliate Beel } & \multicolumn{2}{|c|}{ Shuluar Beel } \\
\hline & Rank & Score & Rank & Score & Rank & Score \\
\hline Strong leadership & 1 & ++ & 1 & +++ & 1 & ++ \\
\hline $\begin{array}{l}\text { Established authority for } \\
\text { resource management }\end{array}$ & 2 & ++ & 2 & +++ & & \\
\hline Participatory decisionmaking & & & 3 & +++ & & \\
\hline $\begin{array}{l}\text { Representation of different } \\
\text { stakeholders }\end{array}$ & & & 4 & +++ & & \\
\hline $\begin{array}{l}\text { Social responsibility among } \\
\text { community created }\end{array}$ & 3 & ++ & & & & \\
\hline $\begin{array}{l}\text { All stakeholders aware about the } \\
\text { project objective }\end{array}$ & 4 & + & 20 & +++ & & \\
\hline $\begin{array}{l}\text { Time maintenance for each } \\
\text { activity }\end{array}$ & 5 & ++ & 8 & +++ & 10 & - \\
\hline Criteria for sustainability agreed & 6 & +++ & & & & \\
\hline Fund created for future activities & 7 & --- & 9 & + & 2 & --- \\
\hline $\begin{array}{l}\text { Responsibility of each member } \\
\text { of the management committee } \\
\text { carried out }\end{array}$ & 8 & ++ & & & & \\
\hline Constitution prepared & 9 & + & 11 & ++ & & \\
\hline Community rules exist & & & 12 & +++ & 4 & +++ \\
\hline $\begin{array}{l}\text { Community compliance with } \\
\text { rules }\end{array}$ & & & 13 & +++ & 5 & + \\
\hline $\begin{array}{l}\text { Cooperation, unity, respect and } \\
\text { perseverance among members } \\
\text { strong }\end{array}$ & 10 & - & 14 & +++ & 3 & + \\
\hline $\begin{array}{l}\text { Members willing to provide own } \\
\text { labor for development work }\end{array}$ & 11 & - & 15 & +++ & & \\
\hline $\begin{array}{l}\text { Cooperation with other NGOs } \\
\text { strong }\end{array}$ & 12 & +++ & 16 & +++ & & \\
\hline
\end{tabular}




\begin{tabular}{|c|c|c|c|c|c|c|}
\hline Committee registered & 13 & -- & 17 & +++ & 6 & +++ \\
\hline $\begin{array}{l}\text { Regular meeting and } 75 \% \\
\text { attendance }\end{array}$ & 14 & +++ & 18 & +++ & 7 & - \\
\hline $\begin{array}{l}\text { Resolution for each meeting } \\
\text { exist and available }\end{array}$ & 16 & +++ & 19 & +++ & & \\
\hline $\begin{array}{l}\text { Linkages with local government } \\
\text { institutions }\end{array}$ & & & 7 & +++ & & \\
\hline Management plans exist & & & 5 & +++ & 8 & ++ \\
\hline $\begin{array}{l}\text { Implement management plans as } \\
\text { scheduled }\end{array}$ & & & 6 & +++ & & \\
\hline
\end{tabular}

Score: rating of achievement of the BMC against these indicators in 2003, on scale of +++ (as good as possible) to - - ( (as poor as possible).

Source: focus groups with BMC members only in 2003 (i.e. Goakhola mixed men and women, Maliate women only, Shuluar men only). 


\section{List of CAPRi Working Papers}

01 Property Rights, Collective Action and Technologies for Natural Resource Management: A Conceptual Framework, by Anna Knox, Ruth Meinzen-Dick, and Peter Hazell, October 1998.

02 Assessing the Relationships between Property Rights and Technology Adoption in Smallholder Agriculture: A Review of Issues and Empirical Methods, by Frank Place and Brent Swallow, April 2000.

03 Impact of Land Tenure and Socioeconomic Factors on Mountain Terrace Maintenance in Yemen, by A. Aw-Hassan, M. Alsanabani and A. Bamatraf, July 2000 .

04 Land Tenurial Systems and the Adoption of a Mucuna Planted Fallow in the Derived Savannas of West Africa, by Victor M. Manyong and Victorin A. Houndékon, July 2000 .

05 Collective Action in Space: Assessing How Collective Action Varies Across an African Landscape, by Brent M. Swallow, Justine Wangila, Woudyalew Mulatu, Onyango Okello, and Nancy McCarthy, July 2000.

06 Land Tenure and the Adoption of Agricultural Technology in Haiti, by Glenn R. Smucker, T. Anderson White, and Michael Bannister, October 2000.

07 Collective Action in Ant Control, by Helle Munk Ravnborg, Ana Milena de la Cruz, María Del Pilar Guerrero, and Olaf Westermann, October 2000.

08 CAPRi Technical Workshop on Watershed Management Institutions: A Summary Paper, by Anna Knox and Subodh Gupta, October 2000.

09 The Role of Tenure in the Management of Trees at the Community Level: Theoretical and Empirical Analyses from Uganda and Malawi, by Frank Place and Keijiro Otsuka November 2000.

10 Collective Action and the Intensification of Cattle-Feeding Techniques a Village Case Study in Kenya's Coast Province, by Kimberly Swallow, November 2000.

11 Collective Action, Property Rights, and Devolution of Natural Resource Management: Exchange of Knowledge and Implications for Policy, by Anna Knox and Ruth Meinzen-Dick, January 2001. 
12 Land Dispute Resolution in Mozambique: Evidence and Institutions of Agroforestry Technology Adoption, by John Unruh, January 2001.

13 Between Market Failure, Policy Failure, and "Community Failure": Property Rights, Crop-Livestock Conflicts and the Adoption of Sustainable Land Use Practices in the Dry Area of Sri Lanka, by Regina Birner and Hasantha Gunaweera, March 2001.

14 Land Inheritance and Schooling in Matrilineal Societies: Evidence from Sumatra, by Agnes Quisumbing and Keijuro Otsuka, May 2001.

15 Tribes, State, and Technology Adoption in Arid Land Management, Syria, by Rae, J, Arab, G., Nordblom, T., Jani, K., and Gintzburger, G., June 2001.

16 The Effects of Scales, Flows, and Filters on Property Rights and Collective Action in Watershed Management, by Brent M. Swallow, Dennis P. Garrity, and Meine van Noordwijk, July 2001.

17 Evaluating Watershed Management Projects, by John Kerr and Kimberly Chung, August 2001.

18 Rethinking Rehabilitation: Socio-Ecology of Tanks and Water Harvesting in Rajasthan, North-West India, by Tushaar Shah and K.V.Raju, September 2001.

19 User Participation in Watershed Management and Research, by Nancy Johnson, Helle Munk Ravnborg, Olaf Westermann, and Kirsten Probst, September 2001.

20 Collective Action for Water Harvesting Irrigation in the Lerman-Chapala Basin, Mexico, by Christopher A. Scott and Paul Silva-Ochoa, October 2001.

21 Land Redistribution, Tenure Insecurity, and Intensity of Production: A Study of Farm Households in Southern Ethiopia, by Stein Holden and Hailu Yohannes, October 2001 .

22 Legal Pluralism and Dynamic Property Rights, by Ruth Meinzen-Dick and Rajendra Pradhan, January 2002.

23 International Conference on Policy and Institutional Options for the Management of Rangelands in Dry Areas, by Tidiane Ngaido, Nancy McCarthy, and Monica Di Gregorio, January 2002.

24 Climatic Variablity and Cooperation in Rangeland Management: A Case Study From Niger, by Nancy McCarthy and Jean-Paul Vanderlinden, September 2002. 
25 Assessing the Factors Underlying the Differences in Group Performance:

Methodological Issues and Empirical Findings from the Highlands of Central Kenya, by Frank Place, Gatarwa Kariuki, Justine Wangila, Patti Kristjanson, Adolf Makauki, and Jessica Ndubi, November 2002.

26 The Importance of Social Capital in Colombian Rural Agro-Enterprises, by Nancy Johnson, Ruth Suarez, and Mark Lundy, November 2002.

27 Cooperation, Collective Action and Natural Resources Management in Burkina Faso: A Methodological Note, by Nancy McCarthy, Céline Dutilly-Diané, and Boureima Drabo, December 2002.

28 Understanding, Measuring and Utilizing Social Capital: Clarifying Concepts and Presenting a Field Application from India, by Anirudh Krishna, January 2003.

29 In Pursuit Of Comparable Concepts and Data, about Collective Action, by Amy Poteete And Elinor Ostrom, March 2003.

30 Methods of Consensus Building for Community Based Fisheries Management in Bangladesh and the Mekong Delta, by Parvin Sultana and Paul Thompson, May 2003.

31 Formal and Informal Systems in Support of Farmer Management of Agrobiodiversity: Some Policy Challenges to Consolidate Lessons Learned, by Marie Byström, March 2004.

32 What Do People Bring Into the Game: Experiments in the Field About Cooperation in the Commons, by Juan-Camilo Cárdenas and Elinor Ostrom, June 2004.

33 Methods for Studying Collective Action in Rural Development, by Ruth MeinzenDick, Monica Di Gregorio, and Nancy McCarthy, July 2004.

34 The Relationship between Collective Action and Intensification of Livestock Production: The Case of Northeastern Burkina Faso, by Nancy McCarthy, August 2004.

35 The Transformation of Property Rights in Kenya's Maasailand: Triggers and Motivations by Esther Mwangi, January 2005.

36 Farmers' Rights and Protection of Traditional Agricultural Knowledge, by Stephen B. Brush, January 2005. 
37 Between Conservationism, Eco-Populism and Developmentalism - Discourses in Biodiversity Policy in Thailand and Indonesia, by Heidi Wittmer and Regina Birner, January 2005.

38 Collective Action for the Conservation of On-Farm Genetic Diversity in a Center of Crop Diversity: An Assessment of the Role of Traditional Farmers' Networks, by Lone B. Badstue, Mauricio R. Bellon, Julien Berthaud, Alejandro Ramírez, Dagoberto Flores, Xóchitl Juárez, and Fabiola Ramírez, May 2005.

39 Institutional Innovations Towards Gender Equity in Agrobiodiversity Management: Collective Action in Kerala, South India, by Martina Aruna Padmanabhan, June 2005.

40 The Voracious Appetites of Public versus Private Property: A View of Intellectual Property and Biodiversity from Legal Pluralism, by Melanie G. Wiber, July 2005.

41 Who Knows, Who Cares? Determinants of Enactment, Awareness and Compliance with Community Natural Resource Management Bylaws in Uganda, by Ephraim Nkonya, John Pender, Edward Kato, Samuel Mugarura, and James Muwonge, August 2005.

42 Localizing Demand and Supply of Environmental Services: Interactions with Property Rights, Collective Action and the Welfare of the Poor, by Brent Swallow, Ruth Meinzen-Dick, and Meine von Noordjwik, September 2005.

43 Initiatives for Rural Development through Collective Action: The Case of Household Participation in Group Activities in the Highlands of Central Kenya, By Gatarwa Kariuki and Frank Place, September 2005.

44 Are There Customary Rights to Plants? An Inquiry among the Baganda (Uganda), with Special Attention to Gender, by Patricia L. Howard and Gorettie Nabanoga, October 2005.

45 On Protecting Farmers' New Varieties: New Approaches to Rights on Collective Innovations in Plant Genetic Resources by Rene Salazar, Niels P. Louwaars, and Bert Visser, January 2006.

46 Subdividing the Commons: The Politics of Property Rights Transformation in Kenya’s Maasailand, by Esther Mwangi, January 2006.

47 Biting the Bullet: How to Secure Access to Drylands Resources for Multiple Users, by Esther Mwangi and Stephan Dohrn, January 2006. 
48 Property Rights and the Management of Animal Genetic Resources, by Simon Anderson and Roberta Centonze, February 2006.

49 From the Conservation of Genetic Diversity to the Promotion of Quality Foodstuff: Can the French Model of 'Appellation d'Origine Contrôlée' be Exported? by Valérie Boisvert, April 2006.

50 Facilitating Collective Action and Enhancing Local Knowledge: A Herbal Medicine Case Study in Talaandig Communities, Philippines, by Herlina Hartanto and Cecil Valmores, April 2006.

51 Water, Women and Local Social Organization in the Western Kenya Highlands, by Elizabeth Were, Brent Swallow, and Jessica Roy, July 2006.

52 The Many Meanings of Collective Action: Lessons on Enhancing Gender Inclusion and Equity in Watershed Management, by Laura German, Hailemichael Taye, Sarah Charamila, Tesema Tolera, and Joseph Tanui, July 2006.

53 Decentralization and Environmental Conservation: Gender Effects from Participation in Joint Forest Management, by Arun Agrawal, Gautam Yadama, Raul Andrade, and Ajoy Bhattacharya, July 2006.

54 Improving the Effectiveness of Collective Action: Sharing Experiences from Community Forestry in Nepal, by Krishna P. Achyara and Popular Gentle, July 2006.

55 Groups, Networks, and Social Capital in the Philippine Communities, by Marie Godquin and Agnes R. Quisumbing, October 2006.

56 Collective Action in Plant Genetic Resources Management: Gendered Rules of Reputation, Trust and Reciprocity in Kerala, India, by Martina Aruna Padmanabhan, October 2006 